\title{
Xebatên Kurdolojîyê Li Zanîngeha Bîngolê (2014-2018)
}

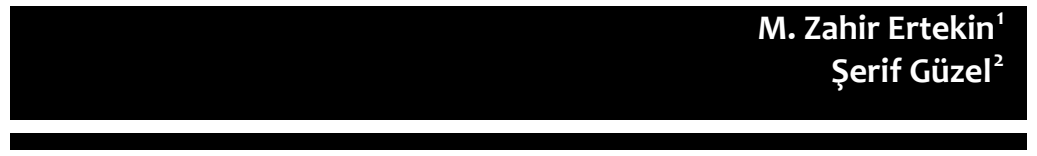

Puxte: Xebatên kurdolojîyê xwe dighinînin sedsala 17em û îro jî çalak berdewam in. Çi bi rêya sazîyên sivîl, çi bi rêya sazîyên fermî yên dewletan, li dormedora cihanê xebatên kurdolojîyê dimeșin. Me di vê nivîsarê de berê xwe daye xebatên Kurdolojîyê li Zanîngeha Bîngolê yên ji sala 2014 heta sala 2018an. Di van salan de, li vê zanîngehê, xebatên di vî warî de hatine kirin bûne naveroka vê gotarê. Di serî de, em li ser tezên kurdolojîyê yên lisans û masterê sekinîn. Piştre em ketin nava gotarên hekemî yên akademik ên vê zanîngehê. Paşê jî berhem û sempozyûmên ku di vê qadê de hatine kirin û weşîyane, kete nava xebata me. Bi vî awayî me xwest em xebatên kurdolojîyê yên vê zanîngehê tomar bikin, îstatîstîkên wan derxin û wek metnekî amadekirî deynin ber destê peywendîdaran.

Peyvên Sereke: Kurdolojî, Zanîngeha Bîngolê, Tezên Masterê, Beşa Kurdî, Doktoraya Kurdî.

\section{Bingöl Üniversitesi Kürdoloji Çalıșmaları (2014-2018)}

Özet: Kürdoloji çalışmaları 17. yüzyıla kadar uzanır ve günümüze kadar devam eden bir sürece sahiptir. Dünyanın değişik yerlerinde gerek sivil kuruluşlar gerek devletin resmi kurumları kürdoloji çalışmalarını yürütmüşlerdir. Biz bu çalışmada Bingöl Üniversitesi'nin 2014'ten 2018 yılına kadar olan kürdoloji alanında yaptığı çalışmalara yöneldik. Bu yıllar içerisinde üniversitenin bu alanda yaptığı çalışmalar makalenin içeriğini oluşturmaktadır. Bu amaçla öncelikle lisans ve yüksek lisans düzeyinde kürdoloji alanında yapılan tez ve bitirme ödevleri üzerinde duruldu. Daha sonra üniversite bünyesinde çıkarılan akademik hakemli makaleler toplandı. Son olarak bu alanla ilgili düzenlenen ve yayınlanan sempozyumlar ve eserler tarandı. Bu şekilde üniversitenin kürdoloji alanıyla ilgili çalışmalarını derlemek, istatistiğini çıkarmak ve yazılı metin haline getirip alanla ilgilenenlere ulaştırmak istedik.

\footnotetext{
Doç. Dr., Bingöl Üniversitesi, Doğu Dilleri ve Edebiyatı Bölümü, zahirertekin@hotmail.com, Orcid: https://orcid.org/0000-0003-3519-9892

2 Öğr. Gör., Bingöl Üniversitesi, Doğu Dilleri ve Edebiyatı Bölümü. serifguzel@bingol.edu.tr, Orcid: https://orcid.org/0000-0003-3837-3155
} 
Anahtar Kelimeler: Kürdoloji, Bingöl Üniversitesi, Yüksek Lisans Tezleri, Kürtçe Bölüm, Kürtçe Doktora.

\title{
Kurdology Studies in Bingol University (2014-2018)
}

\begin{abstract}
The history of Kurdology studies dates back to the 17th century and still it is in progress. Kurdish studies are carried out not only by civil institutions but also by official state institutions all over the world. In this article, we will discuss the Kurdish studies carried out at Bingöl University between 2014 and 2018. The studies carried out in Bingöl University during these years form the content of this article. First, we examined the master and undergraduate theses. Later, we discussed the articles published in the refereed academic journal of this university. Then, we examined the works and symposiums prepared by the university. By doing this, we wanted to record the Kurdish studies in the university, to compile the statistical information, and to present it to the concerned people as a ready text.

Keywords: Bingöl University, Master's Thesis, Kurdish Department, Kurdish Studies PhD
\end{abstract}

\section{Destpêk}

Xebat û lêkolînên derbarê kurdan de bi kurtasî weke kurdolojî dikare bê pênasekirin. Zimanê kurdan bi hemû dîyalektan, mijara sereke û taybet a vê disîplînê ye. Çanda kurdan, siyaseta wan, rewşa civakî, aborîya wan, kevneşopîya wan, jîyan û toreyên wan, edebîyata wan, mêjûya wan û hwd. dikeve qada kurdolojîyê. ${ }^{3}$

Heta niha ji bîyanî û binecihan gelek kesan di vê qadê de kedên mezin dane. Meriv dikare ji wan kesên ku karê kurdolojîyê kirine lîsteyeke dûr û dirêj amade bike û li vir binivîse. Lêbelê emê tenê wek nimûne navên çend kesan zikir bikin. Ji bo kesên binecih, Celadet Alî Bedirxan, Marûf Xeznedar, Eladîn Seccadî, Hecîyê Cindî, Celîlê Celîl, Malmisanij, Rohat Alakom, dikare weke nimûne bê dayîn. Lê dema em kurdologên zimanzan ên binecih, li gorî dîyalektan dabeş bikin, em ê çend mînakên wiha karibin bidin. Ji bo dîyalekta soranî Tewfiq Wehbî (1891-1984) yekem kes e ku xebatên lêkolînî kirine. Wehbî di sala 1926an de Gramera Kurdî diweşîne. Pey re Gîw Mukrîyanî di sala 1950an de ferhengek bi navê Rêber diweşîne bi erebî-kurdî. Paşê di sala 1955an de vê berhemê bi çar zimanan diweşîne. Ji bilî van her du navên ku li ser soranî xebitîne çend navên din jî em dikarin bidin; Dr. Abdullah Hacî Maruf, Muhamed Mukrî, Qadirî Fetahî Qazî, Şêx Merduxî Kurdistanî, Sedîq Safîzade Borekeyî, Hejar, Cemal Nebez, M. E. Hewremanî, Hemîd Ferec, Tahir Sadîq, 'Îzedîn Mistefa Resûl û hwd.

\footnotetext{
3 Martin van Bruinessen, Kürdolojinin Bahçesinde, iletişim, İstanbul 2012, r. 18; Rohat, Kürdoloji Biliminin 200 Yıllık Geçmişi (1787-1987), Weşanên Deng, istanbul 1987, r. 9.
} 
Di kurmancî de; Xelîl Xeyalî, Ordîxanê Celil, Qanadê Kurdo, Ebdullah Cewdet, Salih Bedirxan, Celadet Alî Bedirxan, Kamuran Bedirxan ${ }^{4}$ û hwd. Lîsteya van navan dikare dirêjtir bibe.

Ji bo bîyanîyan jî navên sereke dikare wiha bête jimartin. Alexander Jaba, V. Vêliaminof-Zernov, James Baillie Fraser, Joseph von Hammer, Basil Nikitine, Vilademir Minorsky ${ }^{5}$ û Martin van Bruinessen.

Ji bo zazakî û zazayan Malmisanij ${ }^{6}$, Se’̂̂d Veroj ${ }^{7}$, Roșan Lezgîn ${ }^{8}$, Mehmet S. Kaya, ${ }^{9}$ û Ercan Çağlayan ${ }^{10}$ dikare weke navên sereke bê nişandan. Hin lêkolîner yekem xebata kurdolojîyê ya nivîskî wek gramer û ferhenga Garzonî (1769-1787) Grammatica e Vocabolario Della Lingua Kurda dibînin. ${ }^{11}$ Lê vê dawîyê derket meydanê ku Tesrîfa Teremaxî berî ya Garzonî ye û loma yekem xebata kurdolojîyê ev e. ${ }^{12}$ Helbet li vir mebesta me ne ev niqaş e. Mebesta me ev e ku kurdolojî demeke dûdirêj e heye û îro jî aktîf berdewam e.

Çima me di sernavê nivîsara xwe de peyva "kurdolojî"yê bi kar anî û me çima tenê negot "ziman û edebîyata kurdî"? Lewra dema ku me berê xwe da vê xebatê, me dît ku tezên li Enstituya Zimanên Zindî ya Zanîngeha Bîngolê tenê li ser ziman û edebîyata kurdî nehatine amadekirin. Di tezan de dîrok, çand û rewşa aborî a kurdan jî heye. Herwiha hin sempozyûmên ku li vê zanîngehê hatine weşandin, mijarên li ser dîroka kurdan, rewşa wan a sîyasî û aborî û hemû qadên ku dikevin ber kurdolojîyê, di hundirê xwe de dihewînin. ${ }^{13}$ Loma peyva "kurdolojî"yê ji bo vê xebatê guncavtir hate dîtin.

Li Tirkîyê yekem enstituya fermî ya kurdolojîyê di 10ê Berfanbara 2009an li Zanîngeha Artûklû ya Mêrdîn vebû. Ev enstîtu, ji wê rojê ve xebatên kurdolojîyê, bi taybet li ser ziman û edebîyatê berdewam dike. Ev enstîtu bi navê enstîtuya zimanên zindî hatîye avakirin. ${ }^{14}$ Piştî vê enstîtuyê, 3 enstituyên din jî hatine vekirin, bi heman nav û naverokê. Yek li Wanê yek li Sêrtê û yek jî li Bîngolê. Ji van her sêyan ya Sêrtê aktif nîne. Her duyên din çalakîyên xwe yên kurdolojîyê didomînin. Ya Wanê tenê mastera kurdî dimeşîne lê ya Bîngolê pir texlît û çalaktir xebatên xwe didomîne. Li Zanîngeha Dicleyê û Zanîngeha Muşê, enstîtuya

\footnotetext{
4 Nurullah Alkaç, http://imp-news.com/tr/news/30517/universitelerde-kurdoloji-3 (pêgehîn: 22.11.2018)

Martin van Bruinessen, Kürdolojinin Bahçesinde, İletişim, İstanbul 2012.

6 Malmisanij hem di kurdolojiyê de him jî di warê nivîsîn, çap û weşana zazakî de wek serkirdeyekî dikare bête hesibandin. Ji 70 zêdetir xebatên wî hatine çapkirin.

7 Seîd Veroj, di nêzdîroka kurdan de gelek kesayetên girîng bi belge, lêkolîn û erşîvan derxistiye ser qadê. Wek nimûne; Mihemed Mihrî Hilav, Abdurrahman Nacim, Mewlanzade Rifat, Du Birayên Bedirxanî: Celadet û Kamiran û w.d. Veroj, ev kesayet hemû wek pirtûk çapkirine.

8 Roşan lezgîn, http://www.zazaki.net/ (pêgehîn: 11.110.2018)

9 Mehmet S. Kaya, Zaza Kürtleri, Rûpel Yayınları, İstanbul 2014.

10 Ercan Çağlayan, Zazalar: Tarih, Kültür ve Kimlik, İstanbul Bilgi Üniversitesi Yayınları, İstanbul 2017.

11 Rohat, Kürdoloji Biliminin 200 Yıllık Geçmişi (1787-1987), Weşanên Deng, İstanbul 1987.

12 Mela Eliyê Teremaxî, Tesrîfa Teremaxî, (Metn û Analîz: Merdan Newayî), Nûbihar 2018.

13 Bnr. Kimlik Kültür ve Değişim Sürecinde Osmanlı'dan Günümüze Kürtler Sempozyumu, Bingöl Üniversitesi Yayınları, Bingöl 2013; Jan Vandeburie, (çev.) Bedrettin Basuğuy, “O, Îslam'ın Zaferi Için Ne Çok Gayretliydi!” Selahaddin-i Eyyubi'nin Kudüs Haçlı Krallığı'na Karşı Uyguladığı Strateji(1171-1187), r.147-158.

${ }^{14} \mathrm{Bnr}$. http://www.artuklu.edu.tr/yasayan-diller-enstitusu/enstitumuz (pêgehîn: 02.11.2018)
} 
zimanên zindî tune, lê bernameyên master û doktorayê di bin sîbera enstîtuya zanistên civakî de tên meşandin. Her sê jî di bin banê zanîngehan de vebûne.

Ji bilî enstîtuyan beşên kurdî jî vebûne ku dîsa ya yekem li Zanîngeha Artûklûyê, di sala 2010an de vebûye û di Zanîngeha Mûș û Bîngolê de jî heman beș vebûye û her sê jî aktîf in. Li Zanîngeha Wanê û Dicleyê jî beşên lîsansê yên kurdî di fermîyetê de hene, lê xwendekar nehatine girtin. Mijara vê nivîsarê bi taybet xebatên kurdolojîya zanîngeha Bîngolê ye. Loma em ê li ser kurdolojîya zanîngehên din ranewestin. Herwiha bi hemû layenan em ê berê xwe bidin xebatên kurdolojîyê yên vê zanîngehê, ne tenê yên beşa kurdî û enstîtuya zimanên zindî.

Lêkolînên herî girîng ên ku di vê nivîsarê de cih digirin xebatên master û doktorayê ne. Ev beșek e vê nivîsarê ye. Ev xebat jî li bin banê enstîtuya zimanên zindî têne meşandin.

Em ê di vê gotarê de tenê li ser xebatên enstîtuya zimanên zindî nesekinin. Herwiha em ê berê xwe bidin beşên lîsansê jî ku ew jî dudu ne. Lewra ev du sal e ku her du beş jî xwendekarên xwe mezûn dikin û di her du beşan de jî, di sala çarem de amadekirina teza lîsansê mecbûrî ye. Mamosteyên beşên zimanê kurdî û zazakî li zanîngeha Bîngolê, bêtir giranîyê didin ser folklora kurdan û ji xwendekaran, li ser beşên din ên kurdî amadekirina tezan naxwazin. Loma gelek kelepûr û alavên folklorîk hatine berhevkirin bi saya xwendekarên lisansa van beşan. Loma em ê tezên lîsansê jî bixin nava vê nivîsarê.

Em ê berê xwe bidin kovarên kurdolojîya Zanîngeha Bîngolê jî. Helbet em ê li ser xebatên derveyî Zanîngehê, yên ku mamoste û xwendekarên wan dimeşînin nesekinin. Tenê em ê li ser kovarên ku li ser navê beş an enstîtu an fakulteyan hatine derxistin bisekinin. Herwiha pirtûkên ku zanîngehê weşandine yên bi mijara me re têkildar, kovarên hekemî yên fakulteyên din û sempozyûm û konferansên ku hatine kirin û pirtûkên wan ên ku hatine weşandin jî di binê vê beșê de dê bên nirxandin û îstatîstîkên mijarên têkildarî kordolojîyê ye, di van weşanan/berheman de were ravekirin.

\section{Zanîngeha Bîngolê û Bernameyên Têkıldar bı Kurdolojîyê re}

\subsection{Zanîngehe Bîngolê}

Zanîngeha Bîngolê ${ }^{15}$ di $2007 a n$ de ava bûye. Berî hingê bingeha wê Mekteba Bilind a Pîşeyî bû ku di sala 1983an de girêdayî Zanîngeha Firatê hatibû vekirin. Zanîngeh, îro bi 8 fakulteyan, 2 peymangehên bilind, 5 mektebên bilind ên pîşeyî, 18 navendên lêkolînê û 4 enstîtuyan perwerdehîya xwe didomîne. Di vê zanîngehê de di heyama 2008-2009an de bi fakulteya zîra'etê, dest bi perwerdehîyê hatîye kirin Di nava 10 salan de sazgehîbûna xwe ya bingehîn

\footnotetext{
${ }^{15}$ Di xebatên kurdî yên Zanîngeha Bîngolê de, li ser peyva "Bingol” an "Çewlîg” konsesnusek ava nebûye. Di hin tezan de Bingol” di hinan de "Çewlîg" hatîye nivîsandin. Ji ber vê yekê di nava vê xebatê de wê herdu nav jî derkein pêşberî me.
} 
temam dike û di nava zanîngehên Rojhilata Anatolyayê û Başûrê Rojhilatê Anatolyayê cîyekî taybet û girîng werdigire. Niha ji 15 hezaran zêdetir xwendekarê wê hene û ji hezarî zêdetir jî personelên îdarî li zanîngehê kar dikin. Bi dehan mamosteyên bîyanî jî li zanîngehê wek mamoste dişuxulin. Herwiha bi sedan xwendekarên bîyanî di asta lisans, master û doktorayê de, li vê zanîngehê perwerde dibin. Gelek ji van xwendekaran mezûn bûne û vegerîyane welatên xwe. $^{16}$

\subsection{Bernameyên Têkildar bi Kurdolojîyê re}

\subsubsection{Enstîtuya Zimanên Zindî ya Zanîngeha Bîngolê}

Enstîtuya Zimanên Zindî li Zanîngeha Bîngolê di sala 2011an de vebûye û di 2012an de dest bi wergirtina xwendekaran kiriye. Di binê banê vê enstîtuyê de du binbeş hene. Yek ziman û edebîyata kurdî ya din jî ziman û edebîyata zazakî ye. ${ }^{17}$ Di binê banê her du binbeşan de hem master û hem doktora heye. Master jî dibe du beş. Yek mastera bitez yek jî ya bêtez.

\subsubsection{Mastera Kurdî ya Bitez}

Ji sala 2012an û vir ve xwendekarên mastera kurdî ya bitez, di binê banê enstîtuya zimanên zindî de perwerde dibin. Heta niha 25 xwendekaran tezên xwe qedandine û mezûn bûne. Di vê bernameyê de bi taybetî xwendekarên Kurdistana Iraqê jî serî lê didin û dixwînin. Heta niha 9 xwendekarên bîyanî ji vê bernameyê derçûne.

\subsubsection{Mastera Kurdî ya Bêtez}

Ji sala 2012an û vir ve xwendekarên mastera kurdî ya bêtez, di binê banê enstîtuya zimanên zindî de perwerde dibin. Heta niha 47 xwendekar tezên xwe qedandine, xwe parastine û mezûn bûne.

\subsubsection{Mastera Zazakî ya Bitez}

Ji sala 2012an û vir ve xwendekarên mastera zazakî ya bitez, di binê banê Enstîtuya Zimanên Zindî de perwerde dibin. Heta niha 21 xwendekar tezên xwe qedandine, xwe parastine û mezûn bûne.

\subsubsection{Mastera Zazakî ya Bêtez}

Ji sala 2012an û vir ve xwendekarên mastera zazakî ya bêtez, di binê banê enstîtuya zimanên zindî perwerde dibin. Heta niha 59 xwendekar tezên xwe qedandine, xwe parastine û mezûn bûne.

\footnotetext{
${ }^{16}$ http://www.bingol.edu.tr/tr/universitemiz/genel/tarihce (pêgehîn: 02.11.2018)

${ }^{17}$ http://www.bingol.edu.tr/tr/akademik/enstituler/yasayan-diller-enstitusu/genel-bilgi (pêgehîn: 02.11.2018)
} 


\subsubsection{Doktoraya Kurdî}

Li Bîngolê, doktoraya kurdî bi awayekî hevpar hatiye damezirandin digel Zanîngeha Mûşê. Dayîna dersan û parvekirina xwendekaran di navbeyna du zanîngehan de tê kirin û li her du zanîngehan dersên doktoraya kurdî tên dayîn. Heta niha sê serdeman xwendekar hatine wergirtin. Xwendekarên binecih û bîyanî bi hev re di vê bernameyê de perwerde dibin.

\begin{tabular}{|c|c|c|c|}
\hline 2016 & 2017 & 2018 & Bi Giştî \\
\hline 7 & 10 & 8 & 25 \\
\hline
\end{tabular}

Tablo 1: Wergirtina Xwendekarên Doktorayê (Kurdî) li Gor Salan

\subsubsection{Doktoraya Zazakî}

Doktoraya zazakî tenê li ser navê Zanîngeha Bîngolê hatîye damezirandin. Dayîna dersan û parvekirina xwendekaran li Zanîngeha Bîngolê tê kirin. Di vê bernameyê de heta niha bîyanîyan bo xwendinê murace'et nekirine. Tenê zaza vê bernameyê tercih dikin. Heta niha sê serdem xwendekar hatine wergirtin.

\begin{tabular}{|c|c|c|c|}
\hline 2016 & 2017 & 2018 & Bi Giștî \\
\hline 5 & 2 & 2 & 9 \\
\hline
\end{tabular}

Tablo 2: Wergirtina Xwendekarên Doktorayê (Zazakî) li Gor Salan

\subsubsection{Beșên Lîsansê}

Beșên kurdî bi du navan weke binbeșên beșa ziman û edebîyata rojhilatê hatine avakirin. Yek ji wan ziman û edebîyata kurdî ye, ya din ziman û edebîyata zazakî ye. Beşa ziman û edebîyata rojhilatê jî di bin fakulteya Fen-Edebîyatê de hatîye damezrandin û ji bilî van her du binbeșên navborî, beşa ziman û edebîyata erebî jî çalak e. Niha ji bo beşa kurdî 5, ji bo beşa zazakî 3 û ji bo beşa erebî jî 6 mamoste karê perwerdehîyê berdewam dikin. ${ }_{18}$ Di malpera beșa kurdî de ji bo beşê vîzyoneke wiha hatiye pêşkêşkirin: "Zimanê kurdî (kurmancî) yek ji zimanê herî sereke yê Rojhilata Navîn û dunyayê ye. Ji ber ku li ser erdnîgarîyeke berfireh (Tirkîye, Îran, Iraq, Sûrîye, Ermenîstan û hwd.) belav bûye û ji alîyê hejmarek zêde mirovan ve tê axaftin, kurdîzanî êdî bûye hewcedarîyeke mezin.

Bi vê ramanê, zanîngeha me jî hewl da ku vê hewcedarîyê bi awayekî akademîk û rêkûpêk bi cih bîne. Beşa Ziman û Wêjeya Kurdî, li Zanîngeha Bîngolê de, di sala perwerde û hîndekarîyê ya 2013-2014an de, di bin banê Şaxa Makezanista Ziman û Wêjeyên Rojhilatî de hat damezirandin û niha 40 xwendekar tê de dixwînin. Di heman demê de, di beşa kurmancî de du peywirdarê hîndekarîyê

\footnotetext{
${ }^{18}$ http://www.bingol.edu.tr/tr/akademik/fakulteler/fen-edebiyat-fakultesi/bolumler/dogu-dilleri-ve-edebiyatibolumu/genel-bilgi (pêgehîn: 02.11.2018)
} 
wekî mamoste û pispor kar û barê xwe didomînin. Dema ku xwendekarên me ji vê beșe destûryarî bigirin, wê bikaribin di zanîngeh û sazîyên dewletê de bi hêsanî kar bibînin. Her wiha xwendekarên me wê di qadeke berfireh de derfetên kar û xebatê bi dest bixin." 19

Helbet ev agahî ji bo sala yekê hatîye dayîn. Niha du serdem e ku beş mezûnan dide. Îsal (2018-2019) nifşa sêyem wê mezûnên xwe bidin. Heman rewş ji bo beşa zazakî jî derbasdar e.

Di malperê de ji bo beşa zazakî jî agahî wiha hatîye dayîn: "Beşê Zıwon û Edebîyatê Zazaki serra 2013 dı bîya a. Ina beşa dı, hirıs yew wendekari qêy lisans omê gurewtış. Mıyonê dersoni lisansi dı Gramerê Zazaki, Zıwonnasîyê, Tarixê Zıwonê Zazakî, Metnê Modern ê Zazakî û Metnê Klasik ê Zazaki esti. Ina beşa dı, çar ma'lêmi ders doni. Armancê ına beşa, ze UNESCO zi diqqet ontu cı, Zazakî ha hedi hedi bena vinı, en verni vinbîyayişê zıwonê Zazaki bıyer û Edebîyatê Feki ya Zazakî pe nuştış bıyeru bınê qeydi. Bî ına ma wazeni wa Zazakî perwerdî û ta'lim dı bışuxıl. Wexta ze wendekari ına beşa ra bi mezuni, yi eşkeni hem daironê dewled dı û hem zi daironê xusison dı bıxebıtên. Sera ın daironê dı, mektebonê dewlet, mektebonê xususî, wadeyê çarnayişî, ajansuni, nixweşxonı, daironê adlî û noteron dı yeno."20

\section{Xebatên Kurdolojîyê lı Zanîngeha Bîngolê}

Di vê beşê de em ê cih bidin tezên lîsans û masterê, kovar û gotarên din, kovarên akademîk ên Zîngeha Bingolê de hatine çapkirin; sempozyûm, werger û xebatên din.

\subsection{Tezên Mastirê}

\subsubsection{Mastira Kurdî ya Bitez}

2014

1. Hüseyin Koyuncu, Di Hin Dîwanên Kurdî de Bandora Tesewifê.

2. Cahit Başaran, Kürt Dilinde Sözlükler.

2015

1. Abdurahim Pesen, Helbesta Arjen Arî (Naverok-Şêwe-Binyad).

2. Yakup Aykaç, Dîwana Hezîn (Metn, Lêkolîn û Ferheng.

3. Mehmet Bozkoyun, Çend Çîrokên Herêma Şêxan (Metn-Analîz).

4. Zafer Açar, Devoka Devera Filistanê.

5. Semih Gezer, Dîwana Mela Yasîn Yusrî (Metn û Lêkolîn).

2016

1. Ömer Delikaya, Peyvsazî di Kurmancî de: Nêrîneke Giștî.

\footnotetext{
${ }^{19}$ http://www.bingol.edu.tr/tr/akademik/fakulteler/fen-edebiyat-fakultesi/bolumler/dogu-dilleri-ve-edebiyatibolumu/ana-bilim-dallari/kurt-dili-ve-edebiyati (pêgehîn: 02.11.2018)

${ }^{20} \mathrm{http} / /$ www.bingol.edu.tr/tr/akademik/fakulteler/fen-edebiyat-fakultesi/bolumler/dogu-dilleri-ve-edebiyatibolumu/ana-bilim-dallari/zaza-dili-ve-edebiyati (pêgehîn: 02.11.2018)
} 
2. Seyfettin Aykaç, Mela Mehmûdê Tîruwayî û Ferhenga Wî ya Menzûm (Metn û Lêkolîn).

\section{7}

3. Sedat Gürsu, Bingöl/Kiğı Yöresi Masal Örnekleri ve Tahlili.

4. Türkan Tosun, Edebîyata Zarokan di Kovara Nûbiharê de (1992-2010).

5. Hasan Akboğa, Xelîfe Yûsif û Teqrîza wî (Metn û Lêkolîn.

6. Muhammed İkbal Deniz, Jîyana Seyîd 'Elîyê Findikî û Dîwana Wî.

7. Cihan Turan, Dîwana Fethî (Edîsyon, Metn, Krîtîk).

8. Farset Lafte Ridha Al-Kakî, Rengdanewey Taybetmendîyekanî Sebk-î 'Iraqî le Şi'rekanî Melayê Cizîrî da.

9. Hawkar Jameel Mohammed, Binyadî Gêranewa le Dastanî Mem û Zinî Oskar Mann û Şanoyî Memê Alanî Ebdurehîm Rehmî Hekarî (Lêkolînewekî Berawirdkarîyê).

10. Hana Nawzad Faqe Ibrahim, Gireke Rêzimanî û Ferhengîyekanî Kar le Zimanî Kurdî û Farisî da.

11. Saad Mikaeel Azeez, Surrîyalîzm di Helbesta Nûxazî ya Kurdî de (bi nimûne Helbestên Sebah Rencder).

12. Nimet Baykal, Çend Çîrokên Kurdî yên Dişibin Çîrokên di Gulistana Sa'dî Şîrazî.

$168 \quad 2018$

1. Derin Tahir Sabir, Şi'rîyetî Şi'rî Kosarî.

2.Zafer Atlı, Zeynelabidîn Zinar: Jîyan, Berhem û Senifandina Xebatên Wî.

3. Nurettin Ertekin, Tesewif di Dîwana Şeyda de.

4. Koser Omer Ahmad el Shateera, Şakelîyekan û Rolîyan le Şi'r'ı Kurdî da; Şêx Ehmed be Nimûne.

5. Shaduman Omar Salıh, Cuwankarî le Şi'rî Hewçerxî Kurdî da.

6. Barzan Kanabi Taher, Bas û Xwas Le Manşetî Hewal Rojnamekanî Xebat, Kurdistanî Nûwe û Rojname: Be Numûne Lêkolîneweyekî Simantîkî û Pragmatîkî.

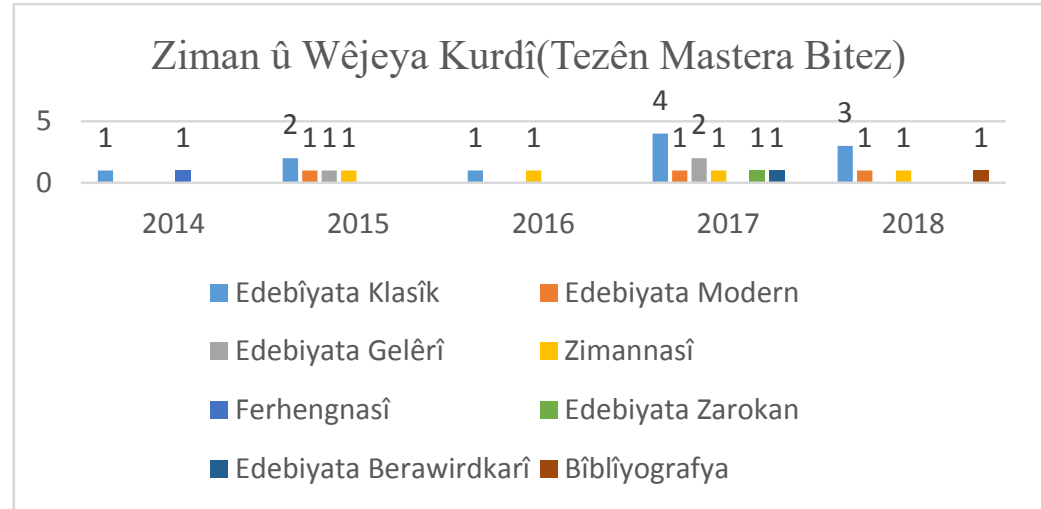

Grafîk 1: Hejmara Tezên Xilasbûyî li gor Sal û Cureyan 


\subsubsection{Mastira Zazakî ya Bitez}

2014

1- Semra Söylemez, Melekan, Gaz ve Muradan Köyleri Zazacasının Ses Değişimi Yönünden Karşilaștırılması.

2- Burçin Asna, Bingöl'de Zazaca Atasözlerinin Tahlili.

3- Abdulkerim Bor, Bingöl Yöresi Zazaca Halk Türküleri.

4- Şahap Yeşilkaya, Edebîyatê Kirdkî (Zazakî) de Mewlid û Mehemed 'Elî Hunî.

5- Mehmet Aslanoğulları, Lerch'in Zazaki Derlemelerinin Çevrimyazımı ve Türlerine Göre Sözcüklerin Tahlili.

2015

1- Hatip Erdoğmuș, Meseleyê Dormalê Darahênî (Metne-Tedqîq).

2- Danyal Apuhan, Vistunikunî Zazakîye Çewlig di Bawerî Bêbinî.

3- Perihan Demir, Zazakî de Derheqê Awanî û Antișî yê Karî Ser Yew Cigêrayîş.

4- Özlem Kılıç, Gramerê Zazakî de Derheqê Negatîfîye Yew Cigêrayîş.

5- Muhsin Aygün, Bingöl Yöresinde Kullanılan Zazaca Hayvancılık Kavramları.

6- Abdurrahman Yılmaz, Zazaca-Türkçe Sözlük, Genç-Bingöl Yöresi.

7- Rıdvan Dolgun, Mintiqaya Darahênî-Zikte de Termê Hacetan û Manayanê Hacetanê ke Cuya Rojane de Şuxulyene.

8- Yusuf Aydoğdu, Modern Zaza Hikayeciliği.

9- Metin Çiftçi, Eqîdenameyo Zazakî yê Mehemedê Hezanîyî (Metno 169 Transkrîbekerde, Wekentiş û Açarnayîş).

2016

1- Murat Varol, Dîwanê Melayê Cebexçurî (Metn û Tehlîl).

2017

1- Ayetullah Karabayeser, Zazakî di Wexti.

2- ibrahim Dağılma, Mewlîdê Xasî û Hetê Me'na ra Wekentişê Mewlîdî.

3- Ahmet Gider, Molla Muhammed Kavarî Dîvânı'nda Din ve Tasavvuf. 2018

1- Büşra Gökalp, Bingöl Masallarında -Seçilmiş Örneklerde- Sembolik Masal Çözümlemeleri.

2- Şahap Laçin, Zazakî de Zerfî û Goreyê Raweyan Şuxulnayîşê Zerfan.

3- Hidayet Samuk, Servi Bölgesi Folkloru. 


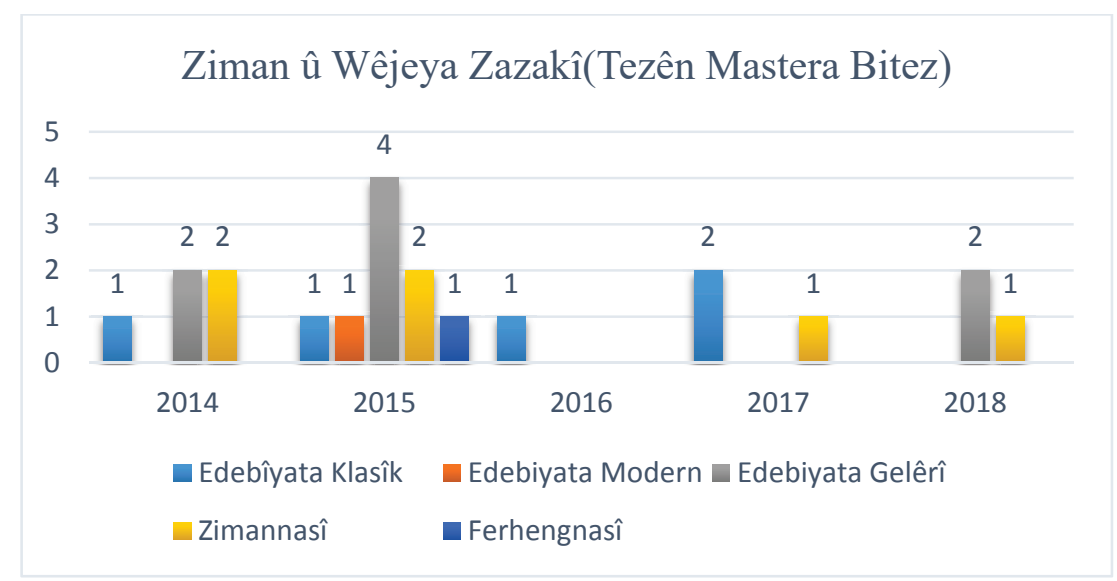

Grafîk 2: Hejmara Tezên Xilasbûyî li Gor Sal û Cureyan

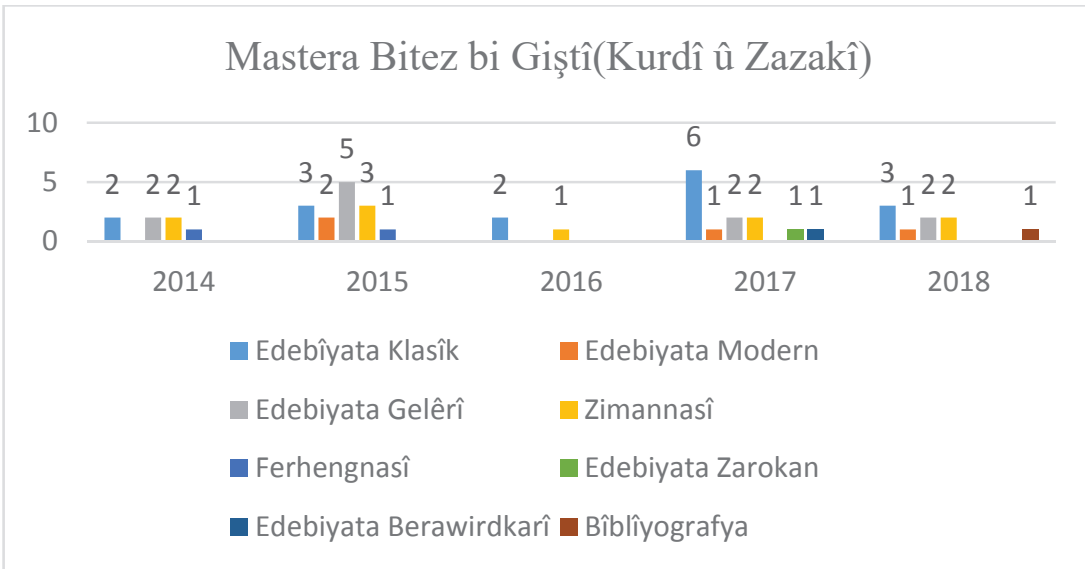
Zazakî)

Grafîk: 3 Hejmara Tezên Mastirê li gor Sal û Cureyan bi Giştî(Kurdî û

\subsection{Projeyên Mastira Bêtez}

\subsubsection{Projeyên Mastira Ziman û Edebîyata Kurdî ya Bêtez}

2013

1- Şahin Çelik, Zenbilfroş Destanı ve Tasavvuf.

2- Mehmet Ali İnanç, Mem u Zin deki Edebi Sanatlar.

3- Şerif Güzel, Hawar Dergisinde Çocuk Edebîyatı Örnekleri.

4- Muammed İkbal Deniz, Baba Tahirin Şiirlerindeki Başlıca Söz Sanatları.

5- Zafer Atlı, Jîyan û Berhemên Nivîskarên Kurd ên ku di Sedasala zoan de Jîyane.

6- Sedat Erdoğan, Di Felsefa Îslamê de Cihê Ehmedî Xanî.

7- Abdullah Altındağ, Kürt Edebîyatında Romancılık. 
8- Abdullah İnanır, lyi Kötü Çatışması Bağlamında Kanon Bir Örnek: Zembilfıroș.

9- Yılmaz Kaval, Hakkâri ve Folkloru.

10- Mahmut Çiftçi, Yapı Bakımından Fiiler.

11- Mehmet Öztunç, Mehmet Uzun'un Romancılığında Geleneksel Kültürün İleri ile Hikâye ve Masal Formu.

12- Gülnihal Pesen, Şeyh Selim Efendi Divanındaki Bazı Edebi Sanatlar.

13- Mustafa Katıksız, Kürtçe'de Kelime Grupları.

14- Yakup Yüksel, Kürtçede Tamlamalar.

15- Ahmet Turan, Dengbej Resonun Hayatı ve Eserleri.

16- Mehmet Bozaba, Yayladere Bölgesinde Kullanılan Kürtçe Atasözleri.

17- Sabır Demir, Mele Nurullahê Godişkî.

18- Şükrullah Kaplan, Bitlis Yöresinde Kullanılan Atasözleri ve Deyimler.

19- Bilal Taşkın, Karlıova Yöresine Ait Hikâye Derlemeleri ve Konuşma Dilindeki Farklılıklar

20- Halit Yılmazer, Kürtçede İsimler.

21- Mehmet Veysi Karakeçili, Şanlıurfa Yöresine ait Yemekler.

22- Mehmet Zîya Bingöl, Zamirler.

23- Saadet Çiçek Bamja, Kürtçede Cümle Çeşitleri.

24- Muhammed Şerif Azarkan, Kürtçede Zarflar.

25- Mehmet Polat, Kürtçe-Farsça Ortak Sözcükler.

26- Ahmet Aksu, Melayê Cızîrî Divanında ve Mem û Zin de iblis Kavramı.

27- Mehmet Katar, Melayê Cızîrî Divanında Musiki.

28- Murat Özbil, Mem u Zin Adlı Eserin Tahlili.

29- Halil Sabak, Kürtçe Zamirler.

30- İmdat Yaman, Bitlis Yöresindeki Dengbejlerin Söyledikleri Kelamlar.

31- Kazım Çimen, Zembilfroş Hikâyesinin Arketipsel Sembolizma Açısından incelenmesi.

32- Cengiz Akyol, Mehmet Uzun ve Edebi Şahsîyeti.

33- Süleyman Yılmaz, Kürtlerin Coğrafyası.

34- Hidayet Yıldırım, Ardahan Yöresi Kürtçe Deyimleri.

35- Arif Bingöl, Ehmedi Xani Hayatı ve Eserleri.

36- İbrahim Kîymaz, Ehmedi Xanide Aşk.

37- Ömer Afşin, Bingölde Tarım ve Hayvancılıkta Kullanılan Aletler ve Kürtçe Karşılıkları.

38- Leyla Acar, Seyyid Aliyê Findık'î'nin Hayatı ve Divanı.

39- Çağdaş Topçu, Melayê Cıziri Divanında Edebi Sanatlar.

\section{4}

1- Melik Taşkın, Kürtçede "N" Harfi ile Başlayan Kelimeler.

2- Veysi Sezer, Lêker (Fiiller).

3- Aynur Taşkesen, Tewang (Bükün).

4- Mehmet Gülli Çağmar, Kürtçede "S" Harfi ile Başlayan Kelimeleri Inceleme. 
5- Cebrail Düzgün, Kürtçe ( Kurmanci ) "Z" Harfi Ille Başlayan Kelimeleri Araştırma.

6- Neşet Bektaş, "L" Harfi ile Sözlük Oluşturma.

7- Recep Cetik, "G" Harfi ille Sözlük Olușturma.

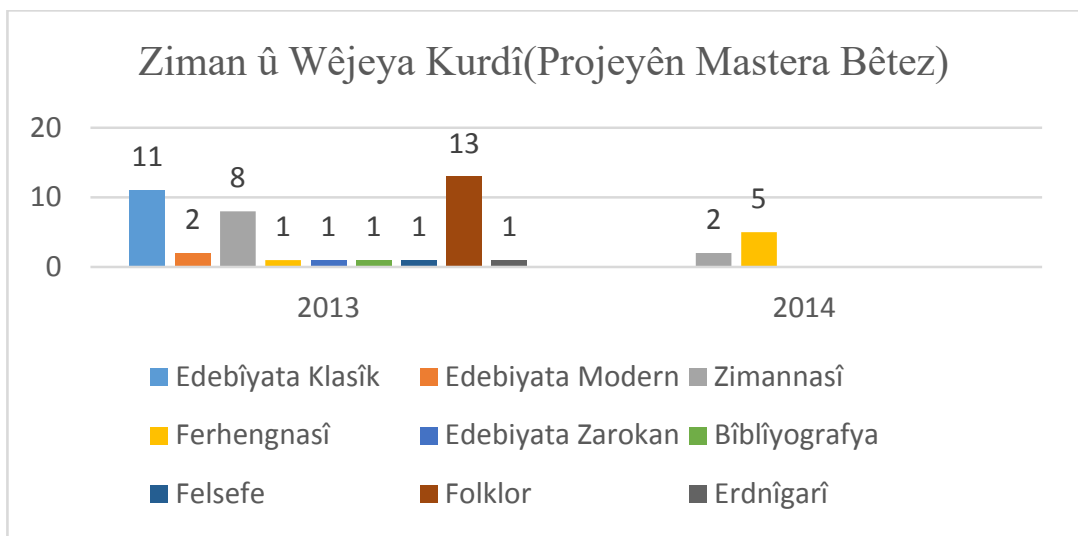

Grafîk: 4 Hejmara Projeyên Xilasbûyî li Gor Sal û Cureyan

\subsubsection{Projeyên Mastira Ziman û Edebîyata Zazakî ya Bêtez}

\section{3}

1- Mahmut Sezgin, Bingöl Yöresi Bilmeceleri.

2- Tunay Varol Özer, Bingöl Zazalarının Gîyim Kültürü.

3- Abdulmutalip Kapar, Zazaca Zamanlar.

4- Fatma Özgökçe, Bingöl Yöresinde Okunan Mela Kamil Puexi'nin Zazaca Yazılmış Şiirleri Türkçe Çevirisi ve Şirirlerin Yorumu.

5- Büşra Gökalp, Türk Basınında Zazaca ve Zazalar.

6- Rıdvan Ayık, Zazalarda Yaşam Materyalleri.

7- Sinan Çibik, Zazacada Inanç Sistemi.

8- Fatih Çağlayan, Bingöl Zazacasında Tamlamalar.

9- ibrahim Dağılma, Zaza Dilinde Dilbilgisi Açısından Isimler.

10- Yunus Bürkük, Zazaca Cümle ve Cümle Çeşitleri.

11- Mustafa Çeçen, Rençber Aziz'in Hayatı.

12- Hayreddin Dervişoğlu, Zazacada Kulanılan Alfabeler.

13- Haşim Beroje, Genc'in Seyfan Köyünde Yer İsimleri.

14- Engin Artunç, Genç ilç̧esi Köylerinin Eski ve Yeni İsimleri.

15- Harun Bürkük, Bingöl Yöresinde Kejan Aşiretine Bağlı Köylerde Kullanılan Zazaca Atasözlerin İncelenmesi.

16- Seride Artan, Bingöl Yöresine Ait Uzun Hikâyeler.

17- Ali Karan, Arıcak (Mîyoran-Sumserkis) Hikâyeleri.

18- Hasret Orak, Zazalar ve Zazaca Hakında Araştırma Yapan Yabancı Bilim Adamları ve Araştırmacılar.

19- Maşide Biricik, Zazaca Hikâye Tahlili. 
20- Yunus Arslan, Zazacada "A" Harfi ile Başlayan Sözcükleri Toplama.

21- Seyfettin Çintay, Haso Çihancim Masalının Tahlili.

22- Serhat Çağlayan, Cümlenin Öğeleri.

23- Tuba Çetkin, Türkçe Bazı Sağlık Terimlerinin Zazaca Karşılıkları.

24- Mustafa Sertdemir, Zazacadaki Önekli Fiilerin Almancadaki Önekli Fiillere Benzeşmesi.

25- Şahin Çahan, Farsça Zamanlar.

26- Yüksel Polat, Karakoçandaki Zazaların Zazacaya Bakışları.

27- Nurettin Kaygısız, Kawar Yöresindeki Muhtelif Hikâyelerin Tahlili.

28- Zülküf Böçkün, Piran Bölgesi Hikâyeleri.

29- Samet Karabulut, Zazaca Şiirler ve Şairlerin Hayatı.

30- Ali Bor, Bingöl'de Yaşayan Zazaların Zazacaya Bakışları.

31- Görkan Karaca, Pexımber Qey Tutono Zazon Adlı Eseri Üzerine Edebi Bir Araştırma.

32- Illhan Sönmez, Solhan Yöresindeki Eski ve Yeni İsimlerinin Karşılaştırmalı Çalışması.

33- Erdal Bulşu, "D" Harfi ile Başlayan Zazaca Kelimelerin Sözcük Araştırması.

34- Duygu Özateş Ketenalp, " $M$ " Harfinin Sözcüklerde Incelenmesi.

35- Nimet iltaş, "N" Harfinin Sözcüklerde Incelenmesi.

36- Faik Bozkurt, Zîya Gökalp ve Hayatı.

37- Selami Kaya, Zazaca Sıfat Tamlaması.

38- Osman Nuri Yolcu, Dersim Yöresi Zazaca Türküler Aracıllğı İle Dersim ve Bingöl Zazacasının Karşılaştırılması.

39- Edanur Burakgazi, İsim ve İsim Çeşitleri.

40- Memet Bilen, Genel Hatlarıla Zazalar.

41- Ebru Çetkin, Bingöl'de Yaylacılık Geleneği ve Zazacaya Etkisi.

42- Nurullah Vergi, "F" Ve "G" Harfleri Üzerine Sözlük Çalışması.

43- Mühsin Artuk, "Ç” Harfi Sözlük Çalışması,.

\section{4}

1- $\quad$ Ersin Yöndar, Servi Yöresi Deyimler.

2- Mahfuz Çapın, Solhan'ın Düğün Kültürü.

3- Emrah Kalabalık, Zazaca Sözcüklerin Tanıtımı ve Yapısal Analizi.

4- Canan Artunç, "K" Harfi Üzerine Sözlük Çalışması.

5- Ömer Erdem, Birinci Cihan Harbinde Bingöl.

6- Nazım Kalkan, Bir Zazaca Tîyatro Denemesi (Şewqa û Kelaw).

7- Haci Yıldırım, "T" Harfi Üzerine Sözlük Çalışması.

8- Celal Bozağaç, "P” Harfi Üzerine Sözlük Çalışması.

9- Filiz Beki, Kovara Vate de Nimûneyê Edebîyate Şarî.

2015

1- Yüksel Kaynun, Molla Muhammed El-Muradanî El Gencî'nin Mewl'id û Eqîda Zazakî Adı Eserinin Eqîda Zazakî Kısmının Latinize Edilmesi.

2- Mehmet Emin Dinler, Solhan Yöresi Adet ve Dualar. 


\section{6}

1- Hüsamettin Esinti, “X” Harfi Sözlük Çalışması.

2017

1- Faruk Korkutata, Zaza Halk Masallarında Olağanüstü Olaylar.

2018

1- Murat Soysal, Solhan illçesine Bağlı Bazı Köylerin 1940 Yılından Günümüze Kadarki Sözlü Tarihi.

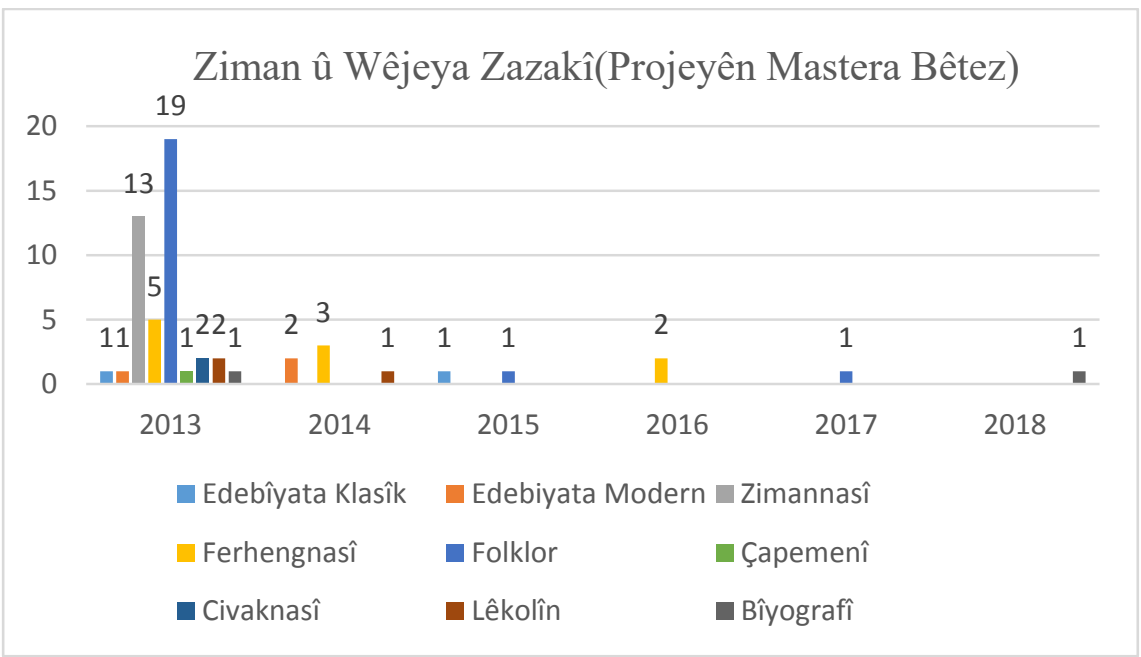

Grafîk: 5 Hejmara Projeyên Xilasbûyî li Gor Sal û Cureyan

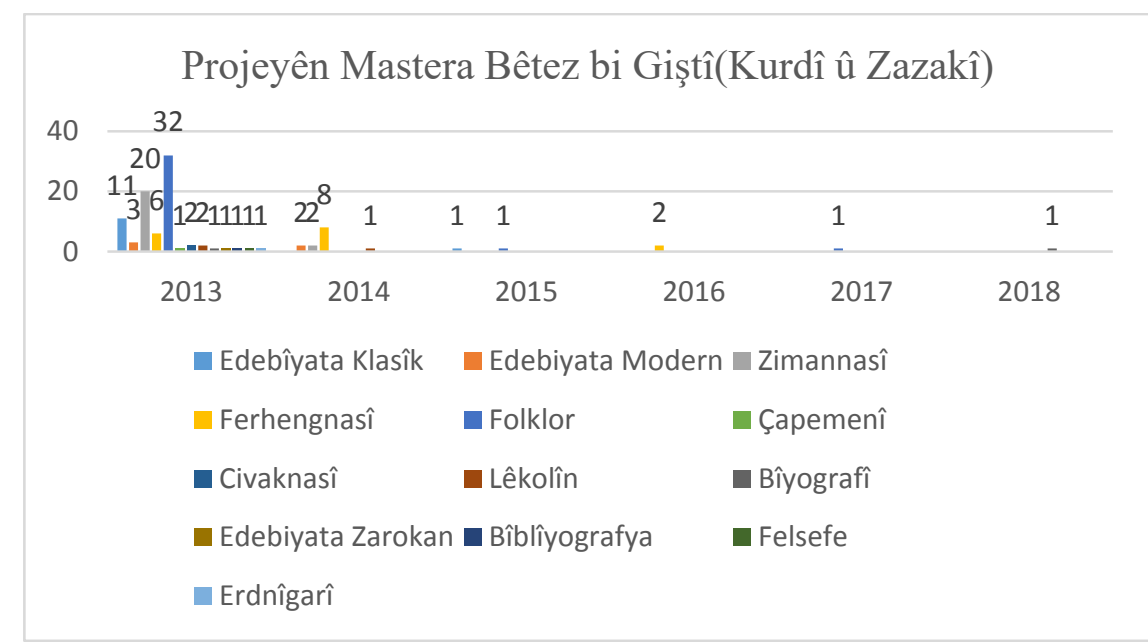

Grafîk 6: Hejmara Projeyên Mastera Bêtez li gor Sal û Cureyan bi Giştî(Kurdî û Zazakî) 


\subsection{Tezên Lîsansê}

\subsubsection{Tezên Lîsansa Ziman û Edebîyata Kurdî}

\section{6-2017}

1- Ahmet Subaşı, Rengvedana Civaka Kurdî di Fablan de.

2- Ahmet Taşkın, Ji Herêma Silopîya Hin Çîrokên Folklorîk.

3- Cihat Aşkan, Hêmanên Folkorîk di Romana Dimdim a Erebê Şemo de.

4- Demet Arga, Motîfên Sereke ji Çîrokên Gundê Şêboya Milazgirê.

5- Emrah Şam, Çanda Dawet û Zewicandinê li Herêma Bedlîsê.

6- Erdal Taş, Motîfên Sereke ji Çîrokên Gundê Serispîya Colemêrgê.

7- Erol Çoban, Şirove û Nirxandinek li Ser Pirtûka Ferhad Pîrbal ya bi Navê Hotêl Europe.

8- Evindar Demir, Çend Hêmanên Folklorîk ji Navçeya Geverê.

9- Fatma Oktay, Berhevkirina Çîrokan ji Herêma Sêrtê.

10- Fehmi Kaya, Çîrokên Gundê Berdehol.

11- Feyzi Dönmez, Bandora Lorikan li Ser Geședana Zimanê Zarokan.

12- Harun Temel, Jîyan û Berhemên Elîyê Evdilrehman û Şîroveyek li Ser Romana Wî ya Xatê Xanim.

13- Hasan Filitoğlu, Şîroveyek li Ser Labîrenta Cinan a Hesenê Metê.

14- Kahraman Aksu, Ji Çanda Kurdî Çend Leyiztikên Kevnare.

15- Kübra Öztürkeri, Dengbêjî û Dengbêj Êma Xecê.

16- M. Salih Turgut, Latînîzekirina 'Tecwîda Mele Mehmûdê Mermerî".

17- Mazlum Özel, Di Gotinên Pêşîyan ên Herêma Colemêrge de Mal û Şexsên Malê.

18- Mehmet Eken, Hejmarên Folklorîk di Çîrokên Kurdî de.

19- Mehmet Emin Akbulut, Çend Taybetmendî ji Edebîyata Êzdîyan.

20- Mem Artemêt, Hêmanên Folklorîk ên Gundê Meşketankê.

21- Mem Erşik, Hin Adetên Kurdan.

22- Mesude Akış, Di Herdu Hejmarên Ewil yên Kovara Folklora Kurdan de Tehlîla Çîrokên Kurmancî.

23- Muhbet Kaya, Tehlîla Çîrokên di Kovara Ronahîyê de.

24- Müzeyyen Pamuk, Edebîyata Zarokan di Kovara Hawarê de.

25- Nazım Aydın, Tehlîla Romana Dewrêşê Evdî Kulîlka Bilbizêk û Rim.

26- Rabia Ay, Hin Motîfên Folklorîk di Çîrokên Navçeya Şemrexê De.

27- Sabri Külter, Tehlîla Romana Helîm Yûsiv ya Gava Masî Tî Dibin.

28- Sinan Atabay, Gotinên Pêşîyan û Biwêjên Belda Kazoxa.

29- Suat Kabukara, Jîyana Hesenê Metê û Analîzek li Ser Berhema Wî ya bi Navê Labîrenta Cinan.

30- Şakire Karabudak, Çend Çîrok ji Derdora Semsûrê.

31- Şükrü Demir, Wergera Pirtûka bi Navê "Ev Exlaqê We ye Kur û Keçên Min"

32- Şükrü Nart, Hecîyê Cindî û Hewarîya Wî.

33- Tarcan Kesici, Tehlîla Çîrokan di 5 Hejmarên Ewil ên di Kovara Hêvî yê de.

34- Tufan Yamaç, Di Radyoya Rewanê de Hêmanên Folklorîk. 
35- Zozan Bozyel, Di Pirtûka Kurdê Rêwî de Du Nimûneyên Folklorîk; Gotinên Pêşiyan û Biwêj.

36- Zübeyir Durmaz, Bawerîyên Pûç di Çanda Kurdî de.

37- Hayal Yıldız, Di Kurdî û Tirkî de Gotinên Pêşîyan ên Hevpar.

2017-2018

1- Aycan Baykara, Berhevkirin û Tehlîla Çîrokên ji Herêma Sêrtê, (Devera Êruh).

2- Hakki Özgün, Ji Herêma Omerîyan-Serêkanîyê Hinek Keresteyên Folklorîk.

3- Ferhad Mamuk, Çîrokên Gelêrî ji Navçeya Şaxê(Wan-Şax).

4- Sinem Ceylan, Ji Devera Şirnexê Hin Keresteyên Folklorîk.

5- Semra Bozkurt, Çend Çîrok ji Herêma Cizîrê.

6- Şenay Asutay, Romanê Denîz Gunduzî o Kalaşnîkofî de Rêçê Ermenîyan û Dejê Hempar.

7- Ayfer Karadoğan, Ji Devera Depê Çîrok û Tehlîla Wan.

8- Medeni Taş, Çend Nimûneyên Lîstikan ji Herêma Midyadê.

9- Serhat Tarhan, Berhevkarîya Çîrokan li Karazê(Metn û Lêkolîn).

10- Hasan Kaçmaz, Ji Herêma Çêrmûgê hin Keresteyên Folklorîk,

11- Hülya Alpkaya, Hin Nimûneyên Folklorîk ji Çanda Kurdî.

12- Ferhat Perdeci, Çend Çîrok ji Derdora Amedê.

13- Levent Boran, Ji Devera Îdirê Hin Berhemên Folklorîk.

14- Zeynep Yıldız, Ji Herêma Batman û Erxenîyê Çend Çîrok.

15- Cahit Severcan, Çend Çîrok ji Gundê Nêrdûşêya Şemzînanê.

16- Elif Nur Aybi, Dengbêjên Bîngolê.

17- Yusuf Kanat, Baxek ji Herêma Colemergê.

18- Hüseyin Tayar, Qevdek ji Folklora Farqînê.

19- Feza Kurhan, Berhemên Folklorîk ji Batmanê.

20- Fedile Avcil, Çend Mînakên Folklorê ji Herêma Hîzanê.

21- Aydın Okyay, Tehlîla Romana Helîm Yûsiv ya bi Navê "99 Morîkên Belavbûyî".

22- Zeynep Acar, Ji Herêma Nisêbînê Çîrok (Mêrdîn, Nisêbîn).

23- Tekin Çoban, Çend Mînakên Folklorîk ji Mem û Zîna Ehmedê Xanî.

24- Abdullah Çiftçiler, Rexneyek li Ser “Kobanî”ya Jan Dost.

25- Recep Ceyhan, Kevneşopîyên Berî Jidayîkbûnê, Piştî Jidayîkbûnê û Zaroktî: Farqîn Weke Nimûne(Vekolîn-Senifandin).

26- Piro Temel, Ji Herêma Şemrexê Berhevkarîya Hinek Keresteyên Folklorîk.

27- Murat Kara, Çîrokên Gelêrî ji Herêma Bazîdê.

28- Muhammed Çaçan, Çend Hêmanên Folklorîk ji Navçeya Pasûrê.

29- Metin Çakır, Çend Çîrokên Foklorîk ji Herêma Sêrtê.

30- Hülya Berke, Hin Keresteyên Folkorîk ji Herêma Agirîyê.

31- Ercan Tekin, Hin Çîrokên Gelêrî ji Navçeya Şaxê ya Wanê.

32- Enise Arslan, Çend Mînakên Folklorîk ji Herêma Geverê.

33- Serhat Kaya, Varyanta Çîroka Mîrze Mihemmed ji Navçeya Gîhadînê ya Agirîyê. 
34- Perihan Fındık, Li Herêma Silopîya Çend Hêmanên Folklorîk.

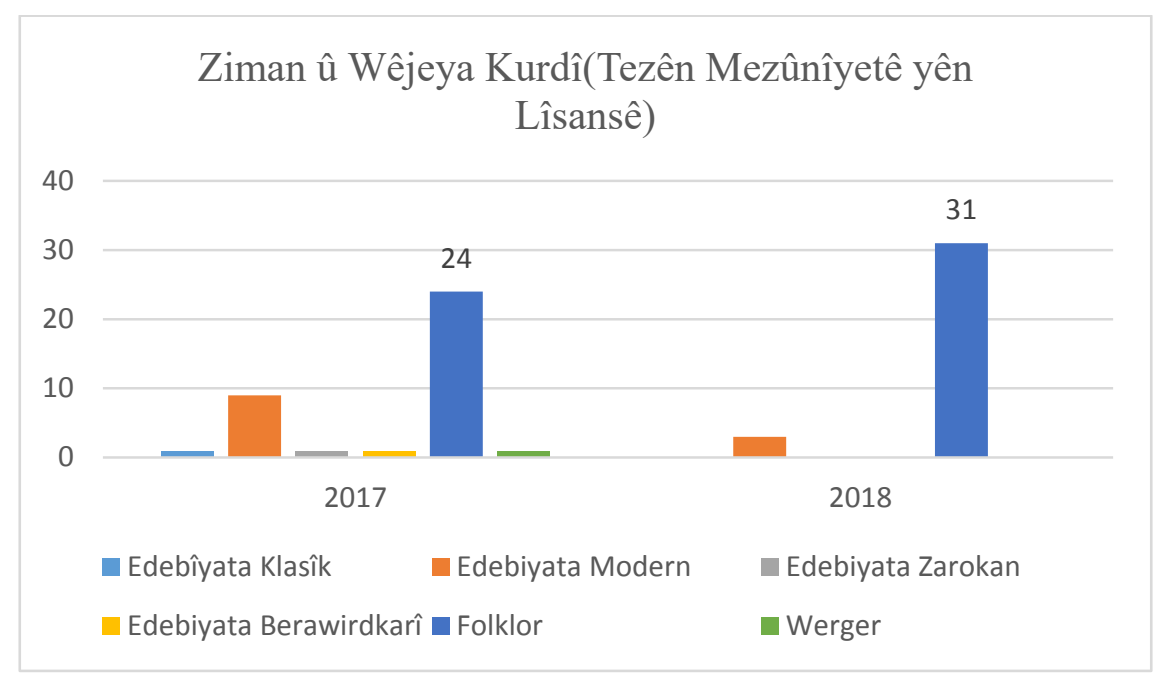

Grafîk: 7 Hejmara Tezên Xilasbûyî li Gor Sal û Cureyan

\subsubsection{Tezên Lîsansa Ziman û Edebîyata Zazakî}

2016-2017

1- Ayşe Ortakaya, Eskihan Köyü Folklor Derlemesi.

2- Şahap Laçin, Zazakî (Kirdkî) de Çekuyê Hemmanayî.

3- Aysel Balık, Şiiranê Nevzat Valeri de Tema.

4- Fatih Tiken, Cuyayiş u Xebatê Malmîsanijî.

5- Neslihan Temel, Kayê Qıcan (Domanan).

6- Pervin Septioğlu, Folklorê Qerebeganî.

7- Mehmet Kaçmaz, Mintiqaya Puex di Mizah ser Arîdayiş.

8- Mervenur Yıldız, Vıstonikonê û Hikâyeyi Bongilan ra Çend Numuneyi u Guereyê Motifanî Tahlilê Inon.

9- Mesut Aslan, Dewa Bamûsî ser o Cigêrayîş û Arêdayîș.

10- Elif Hatısaru, Yeşilköy ve Dikme Köyünün Folklorik Benzerlikleri ve Farklılıkları.

11- Ahmet Çenşi, Estanikanê Sêwregî de Motîfê Heywanan.

12- Âdem Aydın, Heșt Hebî Estanikan de Motîfa Luye.

13- Mehmet Nasip Yıldız, Mintiqayî Çolîg û Dîyarbekîr ra 16 Hebi Efsaneyî û Tehlîlê Motîfê.

14- Ruşen Ayhan, Pîran ra 12 Istonikî û Tehlîlê Motifî.

\section{7-2018}

1- Esra Miran, Kari.

2- Elif Bürke, Estanıki Az (Üçyaka).

3- Sami Yardımcı, Çanayişê Kıtabê Welato Vindbîyaye (Kayıp Ülke). 
4- Hüsamettin Ölmez, Hikaye u Vistoniki Qerebegu.

5- Yunus Emeç, Folklorê Dewa Kurik.

6- Mehmet Ayaz, Xebatê Folklorê Dewa Bazmind.

7- Semavi Aldemir, Sanikê Mintiqayê Qerîxanî.

8- Hülya Orman, Tavz Masallarından Örnekler.

9- Hasan Savsa, Estanikanê Sewreg ra Nimûneyî.

10- Recep Sartık, Mintiqaya Sur sêr Malûmat Aridayîș.

11- Mehmet Sonakalan, Folklorê Dewa Berej.

12- Necmettin Acar, Mintîqaya Mîyalan Sêr Malumat Aridayîş.

13- Buşra Aslan, Mintiqaya Naqşan ra Aredayîş.

14- Erkan İkiz, Folklorê Mintiqaya Hun.

15- Betül Anderiman, Folklorê Mintiqaya Darêyenî.

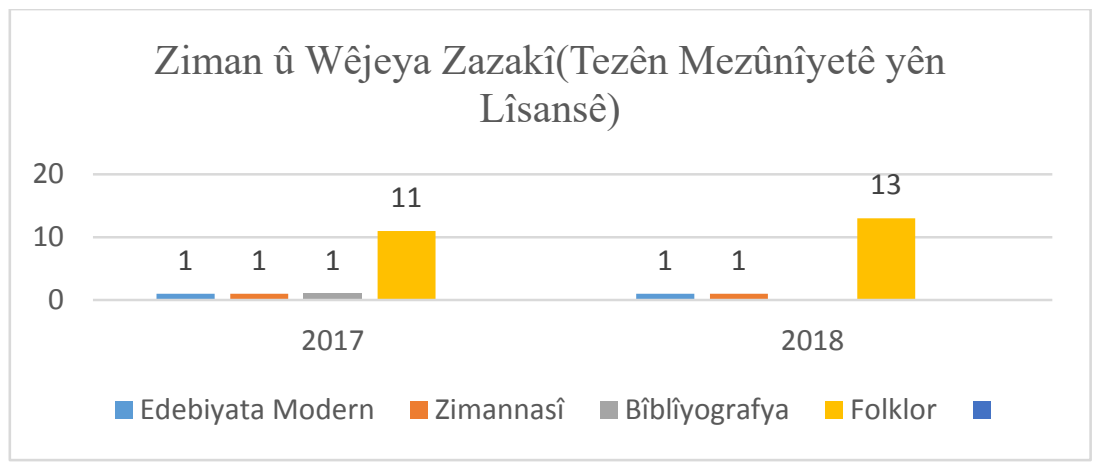

Grafîk: 8 Hejmara Tezên Xilasbûyî li Gor Sal û Cureyan

Tezên Mezûnîyetê yên Lîsansê bi Giştî(Kurdî û Zazakî)

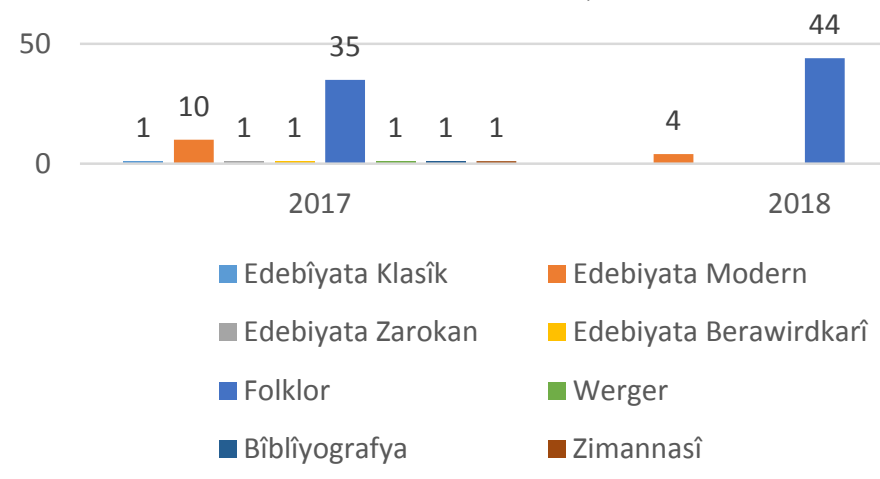

Grafîk: 9 Hejmara Tezên Xilasbûyî li gor Sal û Cureyan bi Giştî(Kurdî û Zazakî) 


\subsection{Kovarên Hekemî}

\subsubsection{Kovara Hekemî ya Enstîtuya Zimanên Zindî ${ }^{21}$}

Kovara enstituya zimanên zindî ya Zanîngha Bîngolê, di çileya 2015an de dest bi weşanê kiriye. Heta niha heşt hejmar derketine. Kovar bi 7 zimanan gotaran qebûl dike: kurmancî, soranî, zazakî, farisî, îngilîzî, erebî, tirkî û almanî. Armanca derketina kovarê; kêmbûna kovarên akademîk yên kurdî ne. Bi vê mebestê kovar dixwaze qadekê ji akademisyenan re veke, da ku gotarên wan ên akademîk bidin çapkirin û li ser kurdan û kurdî çavkanîyekê dirust bike. Pirsgirêka sereke ya kovarê kêmasîya usûla akademîk e di nivîsên kurdî de. Herwiha di belavkirina kovarê de jî her çiqas bêpere be jî tengasî derdikevin. Dîsa peydakirina hekemên hin qadan zehmet e. ${ }^{22}$ Kovar heta niha 8 hejmar derketîye. $^{23}$

\section{Hêjmar 1 û Naveroka Wê}

1- Nusrettin Bolelli, Alfabe'nin İcadı ve Tarih Boyunca Kürtlerin Kullandığı Alfabeler, s.8-27.

2- M. Zahir Ertekin, Li Tirkîyeyê Hin Astengên li Pêş Perwerdehîya Kurdî û Pêşnîyarên Çareserîyê, r.28-38.

3- Murat Varol, Zazaca Yazılan Eserlere Dair Bir Biblîyografya (1899-2014), r.39-54.

4- Yusuf Aydoğdu, Modern Zaza Hikâyeciliğinin Tarihsel Serüveni, r.55-66.

5- Nusrettin Bolelli, Kürt Bilginlerin Yazdıkları Bazı Eserlerin Tanıtımı, r.67-81.

6- M. Zahir Ertekin; Zafer Açar, Di Kurmancî de Cotepeyv û Cureyên Wan, r. 82-92.

7- Mesut Keskin, Zaza Dili, r.93-114.

8- Rasim Bozbuğa, Can 'Zazai Tribe' Mean Anything About The Origin Of Zaza People?, r.115-123.

9- İbrahim Dağılma, Ahmedê Xasînin Hayatı ve Mewlid Adı Eserinde Tema, r.124-146.

10- Hatip Erdoğmuş, Molla Mehmet Demirtaş ve Ehmedê Xanî'de Aşk, r.147156.

11- Ahmet Kesmez, iki Dillilik, Zazaca-Türkçe iki Dilli Akademisyenlerde Dil Kullanımı ve Tercihler, r.157-165.

12- Nevzat Eminoğlu, Di Nûçegihanîya Kurdî de Pirsgirêkên Zimanî, r.166-174. Danasîna Pirtûkan

1- Murat Varol, "Antolojîyê Sairunê Dina” Kitabı Üzerine Birkaç Not, r.175176.

\footnotetext{
${ }^{21}$ Navê kovarê yê resmî ev e; "Bingöl Üniversitesi Yaşayan Diller Enstitüsü Dergisi".

${ }^{22}$ http://www.bingol.edu.tr/tr/arastirma/dergiler/yasayan-diller-enstitusu-dergisi/dergi-yonetimi (pêgehîn: 02.11.2018)

${ }^{23}$ Hemû hêjmarên kovarê li ser malpera dergi parkê hatine weşandin. Bnr. http://dergipark.gov.tr/buydd
} 


\section{Hêjmar 2 û Naveroka Wê}

1- M. Zahir Ertekin, Qelem di Rewdinne'îma Şêx Ebdurrehmanê Aqtepî de, r.8-27.

2- $\quad$ Mehmet Aslanoğulları, Feki Çolig dı Ûntışi Karo Sade ê Zazaki, r.28-47.

3- Abdulcebbar Kavak, Melayê Cizîrî ve Tasavvufî Kürt Edebîyatının Gelişim Dönemi, r.48-66.

4- Süleyman Kasap, A Case Study Related to the First Language Attrition Among Kurdish-Turkish Bilingual Students in Turkey, r.67-8.

5- Roşan Lezgin, Kürtçe'de Akuzatif-Ergatif Özellik, r.82-95.

6- Ömer Delikaya, Nexşeya Zimanî ya Erdnîgarê û Nirxandineke Mîkrotoponomîk li Ser Gundê Qopiza Jorîn, r.96-110.

7- Metin Çiftçi, Edebîyatê Zazakî yê Klasîk de Eqîdenameyî, r.111-122.

8- Hasan Karacan, Mele Hüseynê Bateyî'nin Mewlid-i Nebî Adlı Eseri ile Mele Süleyman Kurşun'un Mewlida Pêxember Adlı Eserinin Karşılaştırılması, r.123-141.

9- Mehmet Bozkoyun, Beşek ji Folklora Kurdî: Çîrok, r.142-157.

10- Yaşar Kaplan, Strana Kurdî (Kurmancî): Devera Hekarîyan Wekî Nimûne, r.158-182.

11- Reșit Yıldız, Di Helbestên Melayê Bateyî de Evîn û Hezkirin, r.183-193

\section{Hêjmar 3 û Naveroka Wê}

180 1- Hasan Çiftci, Ortak Atasözlerinin Hikâyeleri: Farsî-Kurmancî-Zazakî, r.8-22.

2- Mustafa Öztürk, Zûgotinok di Edebîyata Kurdî ya Gelêrî de, r.23-43.

3- Ramazan Pertev, Xebateke Girîng di Dîroka Folklora Kurdî de: Kemal Fewzî û Berhevkarîya Çîrokên Kurdî, r. 44-61.

4- M. Zahir Ertekin, Analîzek li Ser Guldana Hezîn di Çarçoveya Şîretnameyên Kurdî de, r.62-86.

5- Buşra Gökalp, Zazakî de Çekuyê Diletî, r.120-130.

6- Muslih Sezer, Ji Herêma Behdînanê Helbestkarekî Pirziman: Seyfîyê Şoşî, r.131-147.

7- Haşim Özdaş, 'Meala Fîrûz Şerha Qur'ana Pîroz' Adlı Kürtçe Mealde Sözcük Düzeyinde Tercüme Hataları, r.148-164.

8- Zafer Atlı-Şerif Güzel, Mela Huseynê Balekî û Çend Helbestên Wî, r.165-182.

9- Eyüp Gürtürk, Bandora Rêbaza Realîzma Civakparêz di Romana Şivanê Kurmanca de, r.183-196.

\section{Werger}

1- Mehmet Aslanoğulları, Kürtlerin Kökeni, r.87-119.

\section{Krîtîka Pirtûkan}

1- Yusuf Aydoğdu, Tarih-Kültür-Kimlik Kavşağında Bir Halk: Zazalar, r.197200.

2- Hayreddin Kızıl, Danasîna Tefsîreke bi Kurdî Nûra Qelban, Mele Mihemedê Şoşikî, r.201-206. 


\section{Hêjmar 4 û Naveroka Wê}

1- Hasan Çiftci, Ortak Atasözlerinin Hikâyeleri: Farsî-Kurmancî-Zazakî -2, r.821.

2- Mikail Bülbül, Risteyên Peywendîyê û Peyvrêzîya Wan (Devoka Mêrdînê), r.22-45.

3- Süreyya Çetkin, Search of Zazaki Speaking Individuals for Identity, r.46-58.

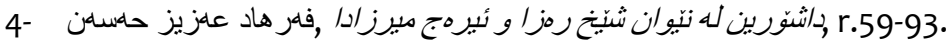

5- Danyal Apuhan, Têveranayışê Tıkê Vateyê Verênan ê Zazaki u Kurmancki, r.94-104.

6- M. Zahir Ertekin, Sê Tezên Mastera Kurdî yên ku li Zanîngehên Tirkîyeyê Hatine Amadekirin -1-, r.126-133.

\section{Werger}

1- Muaz Yakup Muhammed Ronî El-Meranî, Alfabeya Kurdî ya Herî Kevn, r.105-125.

\section{Krîtîka Pirtûkan}

1- Hayreddin Kızıl, Li Ser Pirtûka "Teorîyên Folklorê", r.134-139.

2- Hemin Omar Ahmad, Danasîna Dîwana Mehwî, r.140-144.

\section{Hêjmar 5 û Naveroka Wê}

1- Hasan Çiftci, Ortak Atasözlerinin Hikâyeleri: Farsî-Kurmancî-Zazakî -3-, r.919.

2- Nusrettin Bolelli-Nurettin Ertekin, Ferhengên Menzûm di Edebîyata Kurdî de, r.21-44.

3- Hemin Omar Ahmad, Nalî di Belgenameyên 'Usmanî da, r.45-74.

4- Safia Zevenki, Berhevkirinên Sêmantîkî di Navbera Zimanên Kurdî û Erebî de Derbarê Rewşên Ajelan (Lawiran), r.75-91.

5- Mehmet Aslanoğulları, Keyneka Wayerê Hot Bırayan Sera Tehlilêko Semîyotik, r.93-111.

6- Ibrahim Bingöl, Fonolojîya Devoka Zazakî ya Gimgimê, r.113-128.

\section{Hêjmar 6 û Naveroka Wê}

1- Hasan Çiftci, Ortak Atasözlerinin Hikâyeleri: Farsî-Kurmancî-Zazakî -4-, r.928.

2- Nusrettin Bolelli-Nurettin Ertekin, 'Eqîdeyên Menzûm di Edebîyata Kurdî de, r.29-49.

3- Murat Varol, Şiiri Mulemma ê Şairanê Edebîyatê Zazaki, r.51-65.

4- Mehmet Aslanoğulları, Zazaca ve Kurmancca İsimlerde Çoğulluk, r.67-80.

5- Ahmet Gider, Molla Muhammed Kavarî Dîvânı'nda Ahiret Tasavvuru, r.8194.

6- Pervin Septioğlu, Varyantanê Vıstonıka Waya Hewt Bırayan Ser O Yew Muqayese, r.95-109.

\section{Werger}

1- Ludwig Paul-Murat Alanoğlu (Wer.), Zaza, r.111-113.

\section{Hêjmar 7 û Naveroka Wê}


1- Hasan Çiftci, Ortak Atasözlerinin Hikâyeleri: Farsî-Kurmancî-Zazakî-5, r.950.

2- Ilyas Arslan, Zaza Dilinde Lehçe Farklılıkları, r.51-66.

3- Nesim Sönmez, Tehlîla Nehcu'l-Enama Mela Xelîlê Sêrtî, r.67-85.

4- ibrahim Dağılma, Mehmet Akif Demir u Mewluda Zazaki, r.86-97

5- Bilal Yakışan, Estanıkanê Zazaki Dı Motifê Lu, r.99-111.

\section{Hêjmara 8 û Naveroka Wê}

1- Hasan Çiftci, Ortak Atasözlerinin Hikâyeleri: Farsî-Kurmancî-Zazakî- 6, r.931.

2- Mustafa Öztürk, Çîrokên Gelêrî yên Mela Mehmûdê Bazîdî (1797-1870), r.33-63.

3- Ahmed Ferşbafiyan, Şehriyar'ın Şiirinde Gelenekçilik ve Nostaljiye Bakşı, r.65-83.

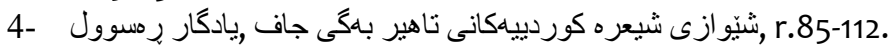

\subsubsection{Kovara Hekemî ya Fakulteya Îlahîyatê}

\section{Hêjmar 1:}

1- Abdulcebbar Kavak, Melayê Cizîrî'nin Divan Şerhleri Arasında "el-ikdu'lCevherî fî Şerh-i Dîvani'ş-Şeyhi'l-Cezerî” Adlı Eser, r.53-67.

2- Jan Vandeburie, (çev.) Bedrettin Basuğuy, “O, Îslam'ın Zaferi İçin Ne Çok Gayretliydi!” Selahaddin-i Eyyubi'nin Kudüs Haçlı Krallığı'na Karşı Uyguladığı Strateji (1171-1187), r.147-158.

\section{Hêjmar 2:}

1- Abdulcebbar Kavak, Mevlânâ Hâlid-i Bağdâdî ve "Akîde-i Îmân" Adlı Eseri Mawlana Khalid Baghdadî and His Work Titled “Akide-i Iman”, r.157-171.

2- Abdulmuttalip Arpa, Şark Medreseleri Programında Kur'ân Birikimi, r.99123.

\section{Hêjmar 6:}

1- Abdulcebbar Kavak, Anadolu'daki İrşad Merkezlerinden Nehrî Tekkesinin Osmanlı Rus Savaşlarındaki Olumlu Katkıları, r.103-123.

\section{Hejmar 7:}

1- Haşim Özdaş Meala Fîrûz' Adlı Kürtçe Mealde Harfî Tercüme Sorunu, r.104118.

\section{Hejmar 9:}

1- Nebi Butasım, Haçlılar Karşısında İslam'ın Sağlam Bir Kalesi Eyyubiler elMelikü's-Sâlih Dönemi (637-647/1240-1249), Bedrettin Basuğuy, (Kitap Tanıtımı), r.288-291.

\section{Hejmar 10:}

1- Mehmet Şirin Ayiş, Bingöl Hâlidî Geleneğinin Medrese Boyutu, r.71-94.

\section{Hejmar 11:}

1- Mehmet Şirin Ayiş, Bingöl ve Çevresinde Halidiliğin Yayılmasında Etkili Olmuş Sufi Şahsîyetler, r.183-208. 


\subsubsection{Kovara Hekemî ya Zanistên Civakî}

\section{Hejmar 5}

1- Murat Varol, Zazaca Kaynaklara Dair Bir Bibliyografya Çalışması, r.145-156.

\section{Hejmar 9}

1- Murat Varol, Zazaca Kaynaklara Dair Bir Bibliyografya Çalışması-2, r.273282.

\section{Hejmar 14}

1- Mehmet Kaya, Simko Ağa İsyanının Türk-Iran ilişskileri Üzerindeki Etkileri (1905-1930), r.201-210.

\subsection{Sempozyûmên Zanîngehê yên bi Kurdolojîyê re Têkildar}

2.4.1 Kimlik, Kültür ve Değișim Sürecinde Osmanlı'dan Günümüze Kürtler Uluslararası Sempozyumu (06-08 Eylül 2012)

1. Ahmet Akgündüz, Osmanlı Tarihinden Günümüze Tarihte Kürtler, r.13-32.

2. Feyzi Güzelsoy, Bediüzzaman Said Nursi'nin Medresetü'z-Zehra Projesi, r.33-37.

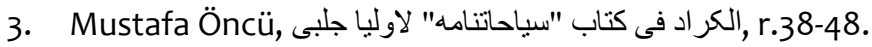

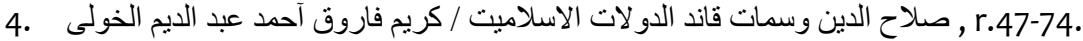

5. Ahmet Demir, Hasanveyhî Hükümdarlarından Ebû'n Necm Bedr B. Hasanveyh el-Kurdînnin Dönemi(369/979-405/1014) ve Şahsîyeti, r.75-97.

6. M. Fatih Çiçek, Osmanlı'dan Cumhuriyete Kürt Milliyetçiliğinin Tarihsel Kökenleri ve Gelișimi, r.98-118.

7. Abdulmutalip Arpa-Kasım Ertaş, Yok Olmaya Yüz Tutmuş bir Kimlik: Ürdün Kürtleri, r.119-128.

8. Mehmet Kavak, Kürdistan'ın Osmanlı'ya Illtihakı ve İdris-î Bitlisînnin Bunda Rolü, r.129-151.

9. Cemal Ülke, Osmanlı Arşiv Belgelerinde Kürdistan Eyaleti ve Kürdistan Eyaletinin Kuruluşu, r.152-172.

10. M. Emin Şen, Il. Abdulhamit'in Kürt Politikası, r.173-181.

11. Orhan Örs, Ittihat ve Terakki Cemîyeti'nin Kürt Politikası 1908-1914, r. 182205.

12. Erdal Aydoğan, Yeni Belgeler Işığında Bitlis Vukuatı, r.206-221.

13. Erdal Aydoğan-Ahmet ilyas, 1927 Nüfus Sayımına Göre Türkiye Cumhuriyeti Devleti'nde Kürt Nüfusu ve Nitelikleri, r.220-231.

14. Mustafa Dağ-Fecri Arslan, 1920'den 2012'ye Suriye Kürtleri, r.232-248.

15. Sadullah Koç, Modern Zamanlara Kalan Millet: Kürtler, r.249-263.

16. Şadi Eren, Irk Realitesi ve Kardeşlik Felsefesi(İslami Ölçüler Çerçevesinde), r.264-282.

17. İsmail Kıran, Üretilen Sosyal Yanılgılar Karşısında Türkiye Toplumu, r.283296.

18. Ahmet ilyas-Orhan Turan, Kürtlerde Aşiret Kavramı ve Oluşumu, r.297305. 
19. Müslüm Polat-Yavuz Türkan, Osmanlı'dan Günümüze Kürtlerde Ekonomik Hayat, r.306-314.

20. Mehmet Yazıcı, Yaşayan Tanıkların Yaşanmışlıkları Işığında Geleneksel Kürt Aile Yapısı ve Aile içi illişkiler, r.315-332.

21. Hasan Fehmi Erdoğmuş, 19.ve 20. Yüzyılda Bingöl ve Çevresinde Kürt Önde Gelenleri, r.333-345.

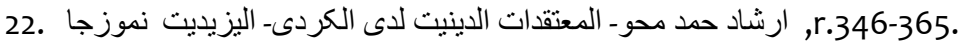

23. Avni Kılıç, Kürdistan'da Halidilik, r.366-379.

24. Halil Çeçen, Melâ Ahmedê Cizîrî'nin Divanı'nda Tasavvufî Unsurlar, r.380391.

25. Halil Akçay, Son Dönem Tasavvuf Âlimlerinden Şeyh Muhammed Emîn elHayderî (Hayatı ve Eserleri), r.392-404.

26. Mustafa Yılmaz Kılınç, Müsbet Millîyet ve Kürtler, r.404-414.

27. Dicle Özcan, Etnisite ve Sivil Toplum İlişkisinde Etnik Bir Grup Olarak Kürtlerin Sivil Toplumculuk Deneyimleri, r.415-430.

28. Rahmi Çiçek, I. Dünya Savaşı ve Sonrası Kürt Kimliği Arayışları, r.431-449.

29. Murat Varol, Etnik Yaklaşımlar Bağlamında Zaza Kimliği, r.450-475.

30. Mehmet Özdemir, Şeyh Ubeydullah Ayaklanması ve Şeyh Ubeydullah'ın Oğlu Seyyid Abdulkadir'in Kürt Milliyetçiliğine Etkisi, r.476-484.

31. Hızır Dilek, Şeyh Sait İsyanının Kürtler Açısından Önemi, r.485-506.

184 32. Hüseyin Güneş, Emeviler Dönemi Sîyasi Olaylarda Kürtlerin Etkinliği, r.507518.

33. Kenan Bozkurt-Emrah Işık, Ehmedê Xani'nin Mem û Zîn'inden Hareketle Kürtlerin Devleşememe Nedenleri, r.519-540.

34. Mehmet Seyman Önder, Osmanlı Devleti ve Türkiye Cumhuriyeti Güvenlik Politikalarında Kürtler; Hamidiye Alayları ve Köy Koruculuğu Sistemi, r.541557.

35. Fecri Arslan-Mustafa Dağ, 1925-1950 Döneminin Siyasal Söyleminde Kürtler: Kürt Raporları Örneği, r.558-576.

36. Abdulbaki Erdoğmuş, Kürt Sorununa Kalıcı Çözüm: Adalet Temayülü, r.577-592.

37. Ahmet Kayıntu, Hastasını Yüzyıldır Bekleyen Reçete, r.593-604.

38. Mehmet Alkış, Türkiye'de Sîyasal Kültür ve Kürd Meselesi, r.605-612.

39. Kazım Yoldaş, Bediüzzaman Said Nursî’nin 31 Mart Vak'asındaki Yatıştırıcı Rolü Bağlamında Kürt Meselesine Bakış, r.613-633.

40. Ramazan Korkut, Said Nursînin Kürt Meselesine Yaklaşımı ve Çözüm Önerileri, r.634-663.

41. Tehsin Ibrahim Doskî, Mîrên Kurd yên Şair û Rola Wan di Pêşvebirina Edebîyata Kurdî da, r.676-682.

42. Ramazan Pertev, Di Edebîyata Kurdî ya Klasîk de Tradîsyona Ferhengnivîsîya Menzûm, r.683-696.

43. Dirbas Mistefa Silêman, Peydabûna Romanê di nav Edebê Kurdî da(Edebîyatên Başûr wek Nimûne, r.697-704.

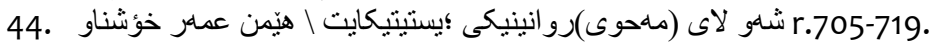


45. Ahmet Kirkan, Tarîxê Weşanî Kurdî de Ekola Şamî, Rolê Haware: Ser Celadet Alî Bedirxan Tetkîkêk, r.720-734.

46. Nurettin Beltekin, Înşayê Nasnameyê Kurdan de Rolê Muzîk ê Polîtîkî: Muzîkê Rençber Ezîz Ser o Yew Tehlîl, r.735-741.

47. Murat Bayram, Çand û Edebîyata Devkî ya Kurdan û Girîngîya Arşîvandina Wan, r.742-747.

48. Cevdet Karaman, Di Klamên Kurdî de Şopa Nêzdîroka Kurda, r.748-775.

49. Abdurrahim Güler, Televizyon Yayınlarının Kürt Dilinin Kullanımına Etkisi: TRT6 ve Dünya TV Örneği, r.776-787.

50. Zelal Özağaçhanlı, Kürtlerde Sözlü Kültür ve Hikâye Anlatıcılığı: Dengbêjlik Geleneği, r.788-807.

51. Canser Kardaş, Dengbêjlik Geleneği ve Şırnak Dengbêjlerinin Gelenekteki Yeri, r.808-816.

52. Kenan Bozkurt, Kürt Masallarının Yapısal Özellikleri, r.817-833.

53. Ramazan Sarıçiçek, Bedirhan Bey Destanı(Legend of Bedirhan Bey), r.834845 .

54. Übeydullah Pilatin, Türk Eğitim Sisteminde Tevhid-i Tedrisat, Eğitim Programları ve Kürtçe'nin Seçmeli Ders Olarak Programda Yer Alması, r.846-858.

55. Tamer Yıldırım, Matbuat Âleminde Mevlanzade Rıfat, r.859-870.

56. Nebi Butasım, Osmanlı Döneminde "Şerefname" Örneği Bağlamında Kürt Minyatür Sanatı Üzerine Değerlendirme. R. 871-883.

\subsubsection{Uluslararası Zaza Dili Sempozyumu (13-14 Mayıs 2011)}

1- Ludwig Paul, Die Herkunft Und Stellung Des Zazaki Und Das Verhältnıs Von Sprache Zu Ethnie / Zazaca'nın Kökeni ve Konumu ve Etnik Kökeni Ile Dilin ilişkisi (Türkçe Çeviri), r.13-24

2- Heiner Eichner, Die Entdeckung und Erste Sprachwissenschaftliche Behandlung Der Sprache Zaza Durch Peter Lerch Und Friedrich Müller /, r.25-30

3- Werner Könı, Sprachatlanten Als Grundlagenwerke Der Sprachwissenschaft / Dilbilimde Temel Eser Olarak Dil Atlasları (Türkçe Çeviri), r.31-48

4- Brigitte Werner, Coding of Background Information in Zazaki Narratıve / Zaza Romanında Temel Bilgilerin Kodlanışı (Türkçe Çeviri), r.49-88

5- Terry L Todd, Phd And Dr. Eberhard Werner, The Sacredness of Mnority Languages And Mother Tongue-Based Multılıngual Educatıon / Azınlık Dillerinin Kutsallığı ve Anadil Temelli Çok Dilli Eğitim(Türkçe Çeviri), r.89109.

6- Zülfü Selcan, Zaza Dili'nin Tarihi Gelişimi, r.111-141.

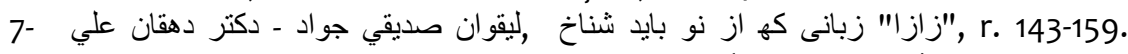
"Zazaca" Yeniden Tanıtılması Gereken Bir Dil (Türkçe Çeviri) / Ali Dehkan, r.161-175. 
8- İsmail Söylemez, Geçmişten Günümüze Zazaca Dergiler: Kronoloji, Sorunlar ve Çözümler, r.175-191.

9- Ali Kemal Özcan, Zazaca (Dımıli) Kürtçe’nın Bir Lehçesi Mi? Kelimelerin "Giz"inde Bir Dil Arayışı, r.193-206.

10- Burhanettin Dağ, Zazaca'nın Farsça ve Deylemi Dillerîyle Olan İrtibatı ve Akrabalığı, r.207-226.

11- Yaşar Aratemür, Arkaik Kaynaklardan Modern Kaynaklara Zazaca ve Zazalar, r.227-246.

12- Ahmet Kasımoğlu, Bitkilerin Zazaca Adlandırılması, r.247-262.

13- Zülfü Selcan, Zazaca Alfabe ve Alfabetik Sıralama, r.263-270.

14- Ercan Çağlayan, Osmanlı Belgelerinde Zazalar ve Zazaca Üzerine Notlar, R.271-290.

15- Fahri Pamukçu, Zazacada Dilbilgisi Zamanları, r.291-311.

16- Murat Alanoğlu-Muhammet Yücel, Dımıli - Zaza Adı ve Tarihsel Gelişimi, r.313-326.

17- Mesut Keskin, Zazacadaki Alfabe Sorununa Bir Bakış ve Çözüm Önerisi, r.327-350.

18- Murat Varol, Zazaca Sözlükçülüğün Tarihi, Sorunları ve Çözüm Yolları, r.351-368.

19- Faruk İremet, Kimliğin Belirlenmesinde Anadilin Önemi!, r.369-384.

20- Hakkı Çimen, Zaza Dili Derslerinin Türkiyéde Kreş ve Okullarda Okutulması, r.375-384.

21- Ayetullah Karabeyeser, Bir Kitle Iletişim Aracı Olarak Televizyonun Zazaca için Önemi, r.385-392.

22- Osman Özer, Zazaca Dil Derlemeleri, r.393-400.

23- Ahmet Kayıntu, Kaybolma Tehlikesi Karşısında Zazacanın Geleceği, r.401412.

24- Hasip Bingöl, Sözün Yazılı Serüveni: Zazakî Dil Çalışmaları Hakkında Bir Kritik, r.413-432.

25- Hıdır Eren, Dil ile Insan Seferi Arasındaki iliş̧ki, r.433-453.

26- Vehbi Türel, Zazakî’nın Geliştirilmesi için ilk Yapılması Gerekenler, r.455462

27- Nebi Butasım, Behistun Anıtında Geçen "Zazana" Kelimesine Dair Eleștirel Bir Yaklaşım, r.463-470.

28- Haydar Şahin, Zazaca Ad ve Soyadların Resmi Kayıt İçin Gramerine Uygun Yazılışı, r.471-482.

29- M. Fatih Çiçek, Siyaset Dili Olarak Zazaca, r.483-494.

30- Sadullah Koç, Zazacanın Dünya Dilleri Arasındaki Yeri Ve Konumu, r.495502.

31- İbrahim Bukan, Uygarlık Tarihinde Zazalar, r.503-530. 


\section{2) \\ 2.4.3. II. Uluslararası Zaza Tarihi ve Kültürü Sempozyumu(04-06 Mayıs}

1- Eberhard Werner, Considerations About The Religions of The Zaza People/Zazaların Dinleri Üzerine Düşünceler(Türkçe Çeviri), r.17-55.

2- Ali Dihkan, سكونتخاه اصلى و خاستخاه اوليه زازاى / Zazaların ilk Yerleşim Yerleri ve Kökenleri(Türkçe Çeviri), r.56-77.

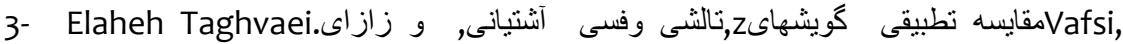
Aştîyani, Talişi ve Zazaca'nın Uygulamalı Mukayesesi (Türkçe Çeviri), r.7885.

4- Ali Kaya, Tarihte Zazalar ve Zazaca, r.86-104.

5- Abdullah Demir, XIX. Yüzyılda Zazaların Nüfusu ve Demografik Yapısı, r.105-145.

6- Kemal Akay, Tarıxê Zazaa de Şiire, r.146-160.

7- Mehmet Tüzün, Désımu De Deyri-Lawuki-Şuari-Hewai, r.161-194.

8- Abdulaziz Beki, Filolojik Açıdan Zazaca'nın Yapısı, r.195-203.

9- İsmail Söylemez, Üst Kültür-Alt Kültür Etkileşimi Bağlamında Zazaca'nın Dilsel Yeterlilik Sorunsalı (Türkiye-Iran Karşılaştırmalı Bir Örneklem Denemesi), r.204-2016.

10- Fahri Pamukçu, Zazakiye Özgünlük Kazandıran Eril-Dişil Algısı, r.217-231.

11- Mesut Keskin, Orta Ve Eski İrani Dillerin Zazacaya Tuttuğu Işık, r.232-252.

12- Burhanettin Dağ, Bazı Zaza Atasözlerinin Kısa İzahı ve Diğer Milletlerin Atasözleriyle Karşılaştırması, r.253-269.

13- Yaşar Aratemür, Zazaca'nın Temel Kelime Hazinesinden Bazı Kelimelerin Diğer Hint Avrupa Dilleri ile Karşılaștırılması, r.270-285.

14- Ercan Çağlayan, Zaza Tarihinin Kaynakları [Arap ve Osmanlı Kaynakları], r.286-301.

15- Hasan Kalcık, Fekî Çewlîgî de Antişî Karan (Fî̀lan), r.302-328.

16- Ahmet Kayıntu, Molla Mehmet Demirtaş'ın Zazaca Divanı, r.329-345.

17- M. Fatih Çiçek, Dünyada Ana Dilde Eğitim Deneyimleri ve Zaza Dilinde Ana Dilde Eğitim Talepleri Üzerine Bir Değerlendirme, r.346-365.

18- Bîlal Zîlan, Tarîxê Xonamekerdişê Kirdan, r.366-397.

19- Ebru Elpe, Zaza Kültürünün Kökenleri, r.398-407.

20- Mehmet Yazıcı, Aleviliğe Etnik Yaklaşımlar: Zazalar - Alevilik iliş̧kisi, r.408425.

21- Nebi Butasım, Zaza Sanatı - Bingöl Örneği, r.426-437.

22- Sadullah Koç, Sözlü Olarak Yaşam Bulan Zazaca'nın Kültür Ve Yaşamla ilișkisi, r.438-443.

23- Abdulmelik Vergi, Zazalarda Zaman Mefhûmu ve Zaza Kültüründeki Yeri, r.444-464.

24- Bedrettin Basuğuy, 19. Yüzyılda Bir Zaza Kadın Şair: Heyran Xanım Dünbülî, r.465-477. 
25- Ramazan Korkut-Abdullah Bedeva, Genel Dilbilim Kapsamında ilk Dönem Arap Dilbilim Çalışmaları Örneğinde Zaza Dilbilim Çalışmalarında Metodolojik Bir Yaklaşım, r.478-489.

26- Fevzi Rençber, Zazaca Konuşan Alevilerin Etnik Kimliği Üzerine Bir Değerlendirme, r.490-499.

27- Nusrettin Bolelli, Zazaca Kitapların Tanıtımı, r.500-516.

28- Osman Özer, Teknolojîye Yenik Düşen Kelimeler, r.517-524.

29- Süleyman Karacelil, Eğitim Kültür Illişkisi: Zaza Atasözlerinde, r.525-540.

30- Abdulmuttalip Arpa, Zazaca'nın Kürtçe'yi Anlama Yeterliliği, r.541-554.

31- Mehmet Kaya, Zazalarda Aşiret Geleneği: Gökdere ve Kasıman Aşiretleri Örneği, r.555-564.

32- Vehbi Türel, Zazakî Masal, Hikâye ve Roman Kitaplarının Hazırlanması, r.565-572.

33- Mustafa Kırkız, 'Meftûn’ Mahlasîyla Ünlü Bir Dünbülî Edibi: Abdurrezzak Beg, r.573-583.

34- Hasip Bingöl, Dilin Terbiye Edilmesi: Makine, Fabrikasyon ve Yalnızlık, r. 584-583.

35- Alaaddin Yüksel - Abdulvahab Baydaş - Ali Rıza Kurtaran, Bingöl Yöresinde Yaşayan Zazalarda Yaylacılık Geleneği, r.603-611.

36- Hıdır Eren, Dersim'in Sosyal Yaşamında "Qol, Salesor, Cırm Ve Kelepur" Kavramları, r.612-624.

37- Murat Varol, Zazalarda Mevlid ve Sîyer Geleneği, r.625-653.

38- Ahmet Kasımoğlu, Xoybûn de Cayê Kirdan, r.654-676.

39- Mehmet Tıraşçı, Zazaca Mevlidler ve Müzikal Olarak İcra Ediliş Tarzları, r.677-688.

40- Nevzat Anuk, Kürt Gazeteciliği ve Zazaca, r.689-712.

41- Zelal Özağaçhanlı, Siverek ve Çevresinde Yaşayan Zazalarda Doğum Geleneği, r.713-729.

42- Mehmet Ali Demirdağ, Merkez Şivesinin Batı Sınırlarındaki Govdere Ağzının Sesbilimsel Yönden incelenmesi, r.730-750.

43- ilyas Arslan, Zazaca'da Partikeller, r.751-771.

44- Ahmet Kırkan, Mewlîdê Zazakî û Mewlîdê Mela Kamîlê Puexî; Hete Edebîyate Qlasîkî ra Qrîtîkêk, r.772-792.

45- Farız Yıldırım - Bilgütay Dursunoğlu, Ad Alınır mı Verilir mi? Bingöl'deki Soyadları Bağlamında Bir Çalışma, r.793-812.

46- Ramazan Korkut, İslam Dini Temelinde Dilbilim Açısından Arapçanın, Kelime Varlığı Alanında Zazaca'ya Etkisi, r.813-852.

47- Rıdvan Dolgun, Türkiye'de Zazaca Nerelerde Konuşuluyor, r.853-860.

48- İbrahim Dağılma, A Menda Mar Muslumantira, r.860-863.

2.4.4. Medrese ve illahîyat Kavşağında İslami illimler(Uluslararası Sempozyum), (29 Haziran-1 Temmuz 2012)

Gotarên vê sempozyûmê di du cildan de hate weșandin. Bi gelek zimanan gelek gotar tê de cih girtine. Yên rasterast bi kurdolojîyê re têkildar û yên 
nerasterasta bi kurdolojîyê re têkildar hene. Me tenê çend ji wanê rasterars bi kurdolojîyê re têkildar bijart.

1. Tehsîn İbrahîm Doskî, Şêweyên Xwandina li Medresên Kurdistanê Devera Badînan Wek Nimûne, r.101-110.

2. Zeynelabidin Zinar, Di nava Medreseyên Kurdî de Girîngîya Medreseya Axtepeyê, r.111-138.

3. Nurettin Beltekin, Vera Modernbîyayîşî de Medreseyê Rojhelatî/Şerqî, r.139-154.

4. Bülent Akot, Nurşin Medresesinin Yetiştirdiği Mutasavvıflar, r. 205-216.

\section{Haziran 2015)}

2.4.5. Toplumsal Barıșın Sağlanması ve Sonrası Sempozyumu(11-12

Gotarên vê sempozyûmê çap nebûne. Hin ji wan gotaran ev in;

1. Hasan Çiftçi, Kürdoloji Akademiasının Sorunları.

2. Murat Varol, Türkiye'deki Üniversitelerde Kürtçe ve Zazaca Üzerine Yapılan Çalışmalara Dair Bir Değerlendirme.

3. Nesim Sönmez, Di Zanîngehan de Pirsgirêkên Beşa Ziman û Edebîyata Kurdî.

4. Ahmet Kırkan, Mardin Artuklu Üniversitesi Yaşayan Diller Enstitüsü'nün Zazaca Lehçesine Katkıları; Eğitim-Öğretim ve Yayın Kapsamında Bir inceleme.

2.4.6. Mevlana Hâlid-i Bağdâdî ve Hâlidiliğin Bingöl ve Çevresi Üzerindeki Etkisi (04-05 Mayıs 2017)

Sempozyum di 4 û 5ê Gulana 2017an de weke sempozyumeke neteweyî hat lidarxistin. Sempozyum ji alîyê Fakulteya îlahîyata Zanîngeha Bîngolê ve hat amadekirin. Di vê sempozyûmê de tevê rûniştina nirxandinê bi tevahî 43 gotar gotar hatin pêșkêşkirin. Hemû gotarên wê di pirtûka sempozyumê de hatin çapkirin. Gotarên ku hatin pêşkêşkirin bi taybetî du mijarên sereke dihewandin. Yek jê jiyan, xebat, têkoşîn, berhem û tesewufa Mewlana Xalidê Şehrezorî bû. Gelek gotar bi hûrgulî û hin ji wan jî bi berawirdî li ser raman û felsefeya Mewlana Xalid sekinin. Ya duduyan jî bi taybetî şaxê Xalidîtîyê li Bîngolê bû. Bîngol jî yek ji wan herêman e ku di bin bandora Mewlana Xalid de gelek xebat û xizmet lê hatiye kirin. Loma di vî warî de cîyekî girîng e. Hin gotar û lêkolîn jî bi taybetî li ser alimên vê deverê yên têkildar bi Mewlana Xalid re û li ser xebatên wan bûn.

Vêca li vir em neșên navên hemû gotaran binivîsin û pêwîst nîne. Eger em Mewlana Xalidê Şehrezorî wek alim û mutesewifekî kurd qebûl bikin, vêca hemû xebatên vê biwarê dikevin binbeșên kurdolojîyê. Loma ev berhem, ji alîyekî tarîxa kurdan vedikole, ji alîyê duyem, kesayetekî kurd ê girîng ronî dike. Loma ev jî weke sernaveke biçûk bû mijara lêkolîna me. Sempozyum weke pdf jî di malpera zanîngehê de cih digire. 


\subsection{Weșanên Zanîngehê}

\subsubsection{Diwon Cepexçuri}

Nivîskarê vê berhemê Abdulaziz Bekî ye. Bi tevayî di dîwanê de ji 130 helbestan zêdetir helbest hene. Zimanê helbestan zazakî, erebî û tirkî ne. Helbestvan di helbestine xwe de navê Azîz bi kar anîye, hin helbestên wî jî bê nav û nişan in. Dîwan bi edîtorîya Murat Varolî di sala 2015an ji nav weşanên zanîngehê der çûye.

\subsubsection{Gramera Çepaxçûrî}

Berhem di sala 2015an de ji nav weşanên Zanîngeha Bîngolê de derçûye. Li ser rêzimana Zazakî agahîyên girîng dihewîne. Nivîskarê wê Abdulaziz Beki ye.

\subsection{Xebatên Dîtir}

\subsubsection{Pirtûkên Dersên Ziman û Zaravayên Zindî yên li Tirkîyeyê}

Ev pirtûk ji alîyê wezareta perwerdehîyê ve tê çapkirin û xwendin. Di sala 2017an de wezaret biryar da; pirtûkên ku ji bo dersên Ziman û Zaravayên Zindî yên li Tirkîyeyê ku li dibistana navîn di pola 5, 6, 7 û 8an de tên dayîn bi taybet yên zazakî, ji layê Zanîngeha Bîngol ve tên amadekirin. Zanîngeha Bîngolê (başa ziman û edebîyata zazakî) ji wana sê heb amade kirine û ev çap bûne, ya çaran li ber çapê ye. Amadekirina pirtûkên kurdî yên bo perwerdehîya dibistanan, cara yekem li Zanîngeha Artûklûyê hatibû amade kirin. Piştre wezara perwerdehîyê ev kar, ji bo kurmancî teslîmî komeke mamosteyên li Batmanê kir û ji bo zazakî jî, ev amadekarî radestî hin mamoste û akademîsyenên Zanîngeha Bîngolê kiriye.

\subsubsection{Laser}

Laser fanzînek e ku xwendekarên beşa Ziman û Edebîyata Kurdî û beşa Zîman û Edebîyata Zazakî di bin banê Kulûba Ziman û Wêjeyê ku kulûbek ji kulüben zanîngehê ye diweşînin. Tê de nivîsên wek ceribîn, helbest, çîrok, werger, folklor, û hwd. hatine nivîs têne weşandin. Heta niha çar hejmar der çûye. Hejmara pêncan dê di demeke nêzik de biweşe. Laser bi kurmancî û zazakî xebatên xwendekaran diweşîne.

\section{Encam û Helsengandin}

Hate dîtin ku li Zanîngeha Bîngolê di nava çar salan de (2014-2018) tibabek xebatên derbarê kurdolojîyê de hatine kirin.

Di serî de bernameyên dualî (bitez û bêtez/kurmancî û zazakî ) yên mastera kurdî gelek xwendekar hatine perwerde kirin, gelek tez derçûne û ev demajo bi awayekî çalak berdewam e.

Li Zanîngeha Bîngolê, çalakîyên wek sempozyûm, panel û konferansên rasterast bi kurdolojîyê ra têkildar, piştî sala 2015an ve nehatine kirin. Ev sempozyûma ku di 2015 an da bi pêvajoya çareserîyê re 'eleqedar bû jî nehatiye çapkirin. Ev rewşên neyînî, rasaterast bi hilweşîna pêvajoyê re têkildar e. Herwiha 
vebûna beşên kurdî û vebûna enstîtuya zimanên zindî jî, parçek ji projeya pêvajoya aşîtîyê bû. Loma em dikarin damezrandina beşên kurdî, lawazbûna wan û xurtbûna wan bi vê pêvajoyê re têkildar bihesibînin. Niha jî beșên kurdî perwerdehîyên xwe berdewam dikin, lê ji layê dewlemendkirina beşan bi mamosteyan hema hema hatiye raddeya sekinînê.

Li gorî salan dema em li mezûnên mastera kurdî ya bitez dinihêrin herî zêde di 2017an de xwendekar derçûne. Ji mastera zazakî ya bitez jî sala herî zêde ku mezûn daye 2015 e.

Di nav tezên mastera kurdî ya bitez de herî zêde edebîyata klasîk hatiye xebitandin. Di nav tezên mastera zazakî ya bitez de herî zêde edebîyata gelêrî hatîye xebitandin.

Di nav projeyên mastera kurdî ya bêtez de herî zêde edebîyata gelêrî hatîye xebitandin. Xebatên vê bernameyê di 2012an de hatiye destpêkirin. Herî zêde xwendekar di sala 2013an de mezûn bûne. Hindik ji xwendekarên vê benameyê jî di 2014an de mezûn bûye. Piștî 2014an xwendekarên ku di vê bernameyê de mezûn bibin tune. Enstîtuyê piştî 2016an xewdekarên mastera kurdî ya bêtez wernegirtiye.

Di nav tezên mastera zazakî ya bêtez de herî zêde xebat li ser zimannasîyê hatine kirin. Xebatên vê bernameyê di zo12an de hatine destpêkirin. Herî zêde xwendekar, herwekî ya kurdî, di sala 2013an de mezûn bûne. Berovajî mastera kurdî ya bêtez, ya zazakî ji 2013an heta 2018an, hindik be jî mezûn dane. Ango ev bername bo zazakî çalaktir xebitîye.

Ji bo tezên lîsansê, di herdu beşan de jî tezên herî zêde di qada edebîyata gelêrî de hatine amade kirin.

Di sempozyûma “Kimlik, Kültür ve Değişim Sürecinde Osmanlı'dan Günümüze Kürtler Uluslararası Sempozyumu” de gotarên hatine pêşkêşkirin piranî bi tirkî hatine nivîîn. Di nava 56 gotarên ku di pirtûka sempozyomê de hatine weşandin de tenê 7 gotar bi kurdî hatine nivîsîn.

Di du sempozyûman de ku li ser zazakî hatine kirin (Uluslararası Zaza Tarihi ve Kültürü Sempozyumu 1 û 2) bi tevahî 79 gotar hatine weşandin, ji van gotaran tenê 5 heb bi zazakî ne. Zimanê gotaran piranî tirkî ye.

Heta niha du pirtûk ji layê zanîngehê ve hatine çapkirin. Yek jê dîwaneke zazakî ye, ya din jî gramera zazakî ye. Nivîskarê herdu berheman jî Abdulaziz Beki ye.

Berhemên perwerdehîyê bo dibistanan ên zazakî ji 2017an ve li zanîngeha Bîngolê têne/hatine amade kirin. Amadekirina pirtûkên kurdî yên bo perwerdehîya dibistanan, cara yekem li Zanîngeha Artûklûyê hatibû amade kirin. Piştre wezareta perwerdehîyê ev kar, ji bo kurmancî teslîmî komeke 
mamosteyên li Batmanê kir û ji bo zazakî jî, ev amadekarî radestî hin mamoste û akademîsyenên Zanîngeha Bîngolê kirîye.

Li Zanîngeha Bîngolê bernameya doktorayê jî bi du alî tê meşandin. Bi taybet doktoraya kurdî di nava sê salan de karekî gelek mezin daye ber xwe. 25 xwendekarên doktarayê ji bo zanîngeha li Bîngolê şoleke serkeftî ye.

Dema em berê xwe didin naveroka tezên masterê, gelek qadên kurdolojîyê derdikevin pêşberî me. Bi taybet di warê ziman û edebîyatê de, gelek qad û beşên jihevcihê hatine şuxulandin û berhemên girîng derketine holê.

Di tezên mastera bêtez û di tezên lîsansê de bi dehan numûneyên cihêreng û ji erdnîgarîyên jihevcuda folklora kurdan hatiye tomarkirin. Hêjaye ku ev berhem, werin ser hev bêne çapkirin, ji bo arşiva folklora kurdî.

Weşanên derbarê kurdolojîyê de hatine kirin ên vê zanîngehê, li gor qamet û ebada xwe hindik nînin. Di gelek kovaran de nivîsarên akademîk çap bûne. Kovareke serbixwe vî şolî bi rê ve dibe û sempozyûmên navneteweyî hatine lidarxistin li vê biwarê de. Ev jî hêja ye ku bala lêkolîner û peywendîdaran bikişîne.

Di tezên mastera kurdî de, ji bo xwendekarên kurdên bakur, ziman tenê kurdî-kurmancî ye. Hemû xwendekarên ku ji kurdistana îraqê hatine bi elfabeya kurdistana başûr û lehçeya xwe tezên xwe nivîsandine/dinivîsînin. Ango kurmancan bi kurmancî û soranan bi soranî nivîsandine. Ev kevneşopî ji bo kurmancî, di tezên lîsansê de jî bi vî rengî ye. Di projeyên mastera bêtez a kurdî de heman qaîde tune. Lewra ev proje, piranî bi tirkî hatine nivîsîn. Hem di mastera zazakî de hem jî di tezên lîsansê yên zazakî de, tezên ku bi zazakî hatine nivîsîn jî hene û tezên bi tirkî hatine nivîsîn jî hene. Xebatên kurdolojîyê yên gotaran cûrbicûr e. Bi kurmancî, zazakî, îngilîzî, 'erebî, farisî, soranî û tirkî em rastî gotarên li ser kurdî-kurdolojîyê yên ku li bin banê Zanîngeha Bîngolê hatine çapkirin, tên.

Ji ber ku heta niha bernameyên doktorayê mezûn nedaye, em nikarin analîzekê li ser wan bikin. Xwendekarên pêşîn wê di payîza 2020 karibin tezên biparêzin. Ancex piştî wê gavê em ê karibin hin şîroveyan bo tezên doktorayê bikin.

Tişta herî bi êş ew e ku dema xwendekarên ku lîsansa kurdî diqedînin, nikarin di qada xwe de karên xwe pêk bînin. Ango nikarin bibin mamosteyên kurdî yên fermî. Lewra her sal 2-3 kes tenê têne te'yîn kirin. Ev jî cîyê xebînetê ye û astengek e li ber pêşveçûna xebatên bi vî rengî.

\section{Çavkanîyên Sereke}

Çağlayan, E. (2017). Zazalar: Tarih, Kültür ve Kimlik, İstanbul: İstanbul Bilgi Üniversitesi Yayınları.

Jan Vandeburie, (çev.) Bedrettin Basuğuy. (2013). “O, Îslam'ın Zaferi İçin Ne Çok Gayretlîydi!” Selahaddin-i Eyyubi'nin Kudüs Haçlı Krallığı'na Karşı Uyguladığı 
Strateji(1171-1187), c.1, hj.1, r.147-158, Bingöl: Bingöl Üniversitesi Illahîyat Dergisi Fakültesi.

Kimlik Kültür ve Değişim Sürecinde Osmanlı'dan Günümüze Kürtler Sempozyumu (2013), (Edt. Cengiz Yıldız), Bingöl: Bingöl Üniversitesi Yayınları.

Bruinessen, M. V. (2012), Kürdolojinin Bahçesinde (Wer. M. Topal). Çapa 1em. İstanbul: iletişim Yayınları.

Kaya, M. S. (2014). Zaza Kürtleri, i̇stanbul: Rûpel Yayınları.

Mela Elîyê Teremaxî. (2018), Tesrîfa Teremaxî, (Metn û Analîz: Merdan Newayî), İstanbul: Nûbihar.

Alakom, R. (1987), Kürdoloji Biliminin 200 Yıllık Geçmişi (1787-1987), İstanbul: Weşanên Deng.

\section{Çavkanîyên Elektronîkî}

Roşan lezgîn, http://www.zazaki.net/

Nurullah Alkaç, http://imp-news.com/tr/news/30517/universitelerde-kurdoloji-3

http://www.artuklu.edu.tr/yasayan-diller-enstitusu/enstitumuz

http://www.bingol.edu.tr/tr/universitemiz/genel/tarihce

http://www.bingol.edu.tr/tr/akademik/enstituler/yasayan-diller-enstitusu/genel-

bilgi

http://www.bingol.edu.tr/tr/akademik/fakulteler/fen-edebîyat-

fakultesi/bolumler/dogu-dilleri-ve-edebîyati-bolumu/genel-bilgi

http://www.bingol.edu.tr/tr/akademik/fakulteler/fen-edebîyat-

fakultesi/bolumler/dogu-dilleri-ve-edebîyati-bolumu/ana-bilim-dallari/kurt-dilive-edebîyati

http://www.bingol.edu.tr/tr/akademik/fakulteler/fen-edebîyatfakultesi/bolumler/dogu-dilleri-ve-edebîyati-bolumu/ana-bilim-dallari/zazadili-ve-edebîyati

http://www.bingol.edu.tr/tr/arastirma/dergiler/yasayan-diller-enstitusudergisi/dergi-yonetimi 